\title{
Ormanlarda zarar yapan böceklerin ekonomik etkileri: Türkiye açısından bir değerlendirme
}

\section{Economic Impact of the Forest Insects: An assessment on studies in Turkey}

\author{
Atakan ÖZTÜRK
}

Artvin Çoruh Üniversitesi Orman Fakültesi Orman Mühendisliği Bölümü, ARTVIN

Eser Bilgisi / Article Info

Araştırma makalesi / Research article

DOI: 10.17474/artvinofd.693430

Sorumlu yazar / Corresponding author Atakan ÖZTÜRK

e-mail: atakanozturk@artvin.edu.tr

Geliş tarihi / Received

24.02.2020

Düzeltme tarihi / Received in revised form

28.03.2020

Kabul Tarihi / Accepted

08.04.2020

Elektronik erişim / Online available

02.05.2020

\section{Anahtar kelimeler:}

Böcek zararı

Ekonomik etki

Orman ekosistem hizmetleri

Orman işletmeciliği

\section{Keywords:}

Insect damage

Economic impact

Forest ecosystem services

Forest management

\begin{abstract}
Özet
Dünya kara yüzeyinin yaklaşık olarak $1 / 3^{\prime}$ ünü kaplayan ve biyolojik kütlesinin de $3 / 4$ ünden fazlasını oluşturan ormanlar; odun ve odun dışı ürünler, biyolojik çeşitlilik, rekreasyonel ve estetik değerler, karbon tutma, su rejimini düzenleme gibi pek çok faydayı bünyesinde barındırmaktadır. Ancak ormanların sahip olduğu bu faydaların varlığı ve sürekliliği çeşitli tahrip faktörlerince tehdit edilmektedir. Ormanlarda farklı şekil ve düzeylerde fiziki ve ekonomik zararlara da neden olan bu faktörler arasında zararlı böceklerin önemli bir yeri vardır. Bu çalışmanın amacı ormanlarda zarar yapan böceklerin ekonomik etkilerinin konuya ilişkin daha önce hazırlanan bilimsel yayınlar ve ilgili belgeler kapsamında irdelenmesidir. Bu amaçla, bazı yabancı ülkeler ve Türkiye ormancılığı için hazırlanan bilimsel yayınlar (makaleler, makaleler vb.) ve belgeler (planlar, raporlar, vb.) içerik analizine tabi tutulmuştur. Yapılan içerik analizleri sonucunda ormanlardaki böcek zararlarına bağlı piyasa odaklı ve piyasa dışı etkiler kapsamında toplam sekiz adet ekonomik etki belirleme yaklaşımı belirlenmiştir. Türkiye'de bu yaklaşımlardan sadece iki tanesine (zarar önleme ve zararla mücadele maliyetleri ile piyasa fiyatı ve işletme gelirlerine etki) ilişkin çalışma yapılmış, kalan altı farklı etki yaklaşımına rastlanmamıştır.
\end{abstract}

\begin{abstract}
Forests that cover about $1 / 3$ of the world land surface and make up more than $3 / 4$ of the biological mass contain many benefits such as wood and wood products, biodiversity, recreational and aesthetic values, carbon capture, and regulation of the water regime. However, the existence and continuity of these benefits of forests are threatened by various destruction factors. The harmful insects have an important place among the factors that cause physical and economical damages in different forms and levels in the forests. The aim of this study is to examine the economic effects of insects that cause damage in forests within the scope of scientific publications and related documents previously prepared. For this purpose, scientific publications (articles, papers, etc.) and documents (plans, reports, etc.) prepared for some foreign countries and Turkish forestry were subjected to content analysis. As a result of the content analysis, a total of eight economic impact determination approaches were determined within the scope of market-oriented and non-market effects related to insect losses in forests. In Turkey, while it was done a few studies for two economic effect determination approaches (loss prevention costs and the market price struggle with loss and its impact on business income), the remaining six kinds of approaches have not been studied.
\end{abstract}

\section{GíRiş}

Sağlıklı bir orman kendini yenileme yeteneği olan, tahrip faktörlerine (böcek, yangın vb.) maruz kalsa da kendini toparlayabilen ve kendisinden elde edilen doğal ve kültürel faydaları sürdürebilen doğal bir ekosistemin temel bileşenlerinden biridir. Sağlıklı orman dinamik bir doğal süreçler bütününü temsil etmektedir (Rosenberger ve Smith 1997).

Dünya kara yüzeyinin yaklaşık olarak $1 / 3^{\prime}$ ünü kaplayan ve biyolojik kütlesinin de 3/4'ünden fazlasını oluşturan ormanlar (Anonim 2001); odun ve odun dışı ürünler, biyolojik çeşitlilik, rekreasyonel ve estetik değerler, karbon tutma, su rejimini düzenleme gibi pek çok faydayı bünyesinde barındırmaktadır. Bu faydaların sürekliliği, faydaları bünyesinde barındıran ormanların sürekliliği ve sağlığıyla yakından ilişkilidir.

Genel olarak biyotik (yangın, zararlı orman böcekleri vb.) ve abiyotik (fırtına, kuraklık vb.) olmak üzere iki grupta toplanan tahrip faktörleri, sağ|ı̆̆ını ve sürekliliğini tehdit ettikleri ormanlarda önemli zararlara neden olmaktadır (Baş 1972). Özellikle zararlı böcekler doğal ormanlar üzerinde en yıkıcı etkiye sahip faktörlerdendir (Ivantsova ve ark. 2019). ABD'de orman zararlılarından (böcek ve 
patojenler) etkilenen yıllık orman alanı, yangından etkilenen orman alanından yaklaşık 45 kat ve böcek zararlarının ekonomik etkisi ise yangınınkinden altı kat daha büyük olarak tahmin edilmiştir (Dale ve ark. 2001).

Ormanlardaki böcek zararlarının etkileri bir anda ortaya çıkmadığından, zararın boyutu ve durumun ciddiyeti ancak böcek salgını kitle halini aldıktan sonra anlaşılabilmektedir (Anonim 1990a). Bu tür salgınlar ormanlarda büyük çaplı ağaç ölümlerine neden olması yanında böcekle mücadeleyi güçleştirmekte ve mücadele maliyetlerini de artırmaktadır.

Diğer ülkelerde olduğu gibi Türkiye'de de mevcut 22.6 milyon ha düzeyindeki orman alanında (OGM 2019) uygun şartların oluşması halinde kitle halinde çoğalarak tahribata neden olan böcekler, ormanlardan faydalanmayı olumsuz yönde etkilemektedir. Bu etkiler sadece ağaç servetinde değil tüm orman fonksiyonlarında görülebilmektedir. Bir başka ifadeyle böceklerin ormanlardan elde edilebilecek tüm mal ve hizmetleri dolayısıyla orman işletmeciliği faaliyetlerini olumsuz yönde etkileme potansiyeli bulunmaktadır.

Genel olarak tüm ülkelerin ormancıllı̆ında sürdürülebilir orman yönetimi uygulamalarını tehdit eden bu etkiler ekolojik ve ekonomik boyutları ile dikkat çekmektedir. Böcek zararına maruz bölgelerde özelikle piyasa işlemleri ve harcamalarına ilişkin veriler kullanılarak tahmin edilen ekonomik etkilerin (McCollum ve Lundquist 2019) çeşit ve düzeylerinin belirlenmesi, böcek tahribatına karşı alınacak tedbirler ve böcekle mücadelenin etkinliği açısından önem taşımaktadır. Ancak böcek zararlarının ekonomik boyutuna ilişkin sorun, genellikle ormanda tahribat doğuran sorunlar içinde ikincil bir sorun olarak algılanmakta (Holmes ve ark. 2008) ve böcek zararlarının ekonomik etkileri üzerinde ekolojik etkilerine nazaran daha az durulmaktadır (Ivantsova ve ark. 2019).

Bu makalede Türkiye ormanlarındaki böcek zararlarının orman kaynaklarının yönetimi / işletmeciliğine dönük muhtemel ekonomik etkilerinin bilimsel çalışma, belge ve raporlarda hangi kapsamda ele alındığının belirlenmesi ve irdelenmesi amaçlanmıştır. Bu genel amaç çerçevesinde esas itibariyle makalede şu soruların cevaplanmasına çalışılmaktadır:
- Ormanlardaki böcek zararları ve ekonomik etkilerine yer veren başlıca akademik çalışmalar ve raporlar ile buralarda öne çıkan bulgu ve değerlendirmeler nelerdir?

- Söz konusu çalışmalarda böcek zararlarının ekonomik etkileri hangi amaç ve kapsamda ele alınmış ve tahmininde nasıl bir yaklaşım / yöntem izlenmiştir?

- Türkiye ile diğer ülkelerdeki çalışmaların benzerlik ve farklıkları nelerdir? Bunlara bağlı olarak Türkiye'de yapılması gerekenler nelerdir?

\section{MATERYAL VE YÖNTEM}

Araştırmada konu ile ilgili yurt içi ve yurt dışında yayımlanmış makale, bildiri vb. akademik çalışmaların yanı sıra çeşitli plan, rapor vb. dokümanlar materyal olarak kullanılmıştır. Bu amaçla Google Akademik (https://scholar.google.com.tr) bilimsel yayın veri tabanında; "orman", "orman kaynakları", "orman zararlıları", "zararlı böcekler", "ekonomik etki", "ekonomik kayıp" ve "mücadele maliyeti" gibi anahtar kelimeler (Türkçe ve İngilizce olarak) birlikte veya ayrı ayrı kullanılarak doküman taraması yapılmıştır. Ayrıca Türkiye'de orman entomolojisi odağında düzenlenen sempozyumların bildirileri ve yayımlanan kitaplar ile ormancilık plan ve programlarından (kalkınma planları, ormancilık özel ihtisas komisyonu raporları, ulusal ormancılık programı ve Orman Genel Müdürlüğü (OGM) yıllık faaliyet raporlarından) da istifade edilmiştir.

Kaynak taraması yardımıyla elde edilen tüm materyaller araştırma amacı doğrultusunda yurt içi ve yurt dışı çalışmalar başlığı altında ayrı ayrı ele alınmış olup, zararlı böceklerin ekonomik etkileri; etki çeşitleri ve etkileri belirlemede kullanılan yöntem ve yaklaşımlar esas alınarak irdelenmiştir. Akademik çalışmalar doğrudan ve dolaylı ilişkili olarak gruplandırılmıştır. Gruplandırmada; ekonomik etkilerin çeşidinin ve / veya miktarının tespitine yönelik bizzat araştırmacı(lar) tarafından elde edilen (birincil) verilere dayalı yöntem / yaklaşımları ve sonuçları içeren çalışmalar doğrudan ilişkili; ekonomik etkilere ilişkin var olan bilgilerden hareketle genel nitelikli tespit ve değerlendirmelere sahip olan veya derleme niteliğinde 
olan çalışmalar dolaylı ilişkili çalışmalar olarak tanımlanmıştır.

\section{TÜRKIYE ORMANCILIĞINDA BÖCEKLERIN EKONOMIK ETKILERi}

\subsection{Ormancılıkla İlgili Makro Plan ve Programlar}

Ülkemizde 1963-2018 yılları arası on adet kalkınma planı (KP) hazırlanmış ve uygulanmış olup, KP'lerde ormancılık amaç ve politikaları bazı dönemlerde müstakil bir sektör olarak ormancılık sektörünün içinde bazı dönemlerde ise başka sektörlerin içerisinde yer almıştır.

Söz konusu planlarda ormancılık sektörünün temel girdisi olan orman kaynaklarının çeşitli tahrip faktörleri ve özellikle de zararlı böceklerin etkisiyle ortaya çıkan ya da çıkması muhtemel zararlar ve bu zararların ekonomik etkilerine / sonuçlarına ilişkin yapılan tespit ve değerlendirmeler ile amaç, ilke, hedef ve politikalar incelendiğinde (Çizelge 1); ilk dört KP'de bu konulara hiç değinilmediği görülmektedir. İlk olarak V. KP'de orman koruma üzerinde etkili olan diğer faktörlerle birlikte, zararlı böceklerle de mücadele edileceğine ilişkin bir politikaya yer verildiği, akabinde tüm KP'lerde (VI, VII, VIII, IX ve $X$. KP) ormanların korunması kapsamında böcek ve benzeri zararlılarla mücadele yöntemlerine ya da zararlılara dayanıklı ormanlar oluşturulmasına ilişkin tespit ve hedeflerin yer aldığı görülmektedir. Genel nitelikli bu değinilerin hiç birinde ormanlardaki böcek ve benzeri zararlıların ekonomik sonuçlarına ilişkin bir tespit ya da değerlendirmeye rastlanmamıştır.

Çizelge 1: Kalkınma planlarındaki durum

\begin{tabular}{|c|c|}
\hline $\begin{array}{c}\text { Dönemi } \\
\text { I, II, III, IV }\end{array}$ & Planda İlgili İfadelerin Bulunduğu Bölümler \\
\hline $\mathrm{V}$ & $\begin{array}{l}\text { II. TARIM } \\
\text { b) ILKELER VE POLITIKALAR } \\
\text { 239. ... (25) Orman koruma programları, yangın, erozyon, böcek, kaçak kesim, açma, plansız yerleşme ve otlatma ile gereğince } \\
\text { mücadele yönünde geliştirilecektir. }\end{array}$ \\
\hline $\mathrm{VI}$ & $\begin{array}{l}\text { II. TARIM } \\
\text { 5. ORMANCILIK } \\
\text { a) Hedefler ... } \\
\text { 298. ...... ormansızlaşma, ... taşkın gibi afetlerin olumsuz etkilerinin azaltılabilmesi için (koruma*), ağaçlandırma, gençleştirme, } \\
\text { erozyon kontrol ve mera ıslah çalışmalarının geliştirilmesi amaçlanmaktadır. }\end{array}$ \\
\hline VII & $\begin{array}{l}\text { 5. TARIMSAL POLiTiKALAR iLE iLGiLi YAPISAL DEĞişiM PROJESi } \\
\text { b) Amaçlar, ilkeler ve Politikalar } \\
\text { Ülke genelinde ... ağaçlandırmalarda böcek ve hastalıklara dayanıklı, .... ormanlar kurulması esas olacaktır. }\end{array}$ \\
\hline VIII & $\begin{array}{l}\text { VIII. TARIMSAL GELIŞME } \\
\text { 5. ORMANCILIK } \\
\text { b) Amaçlar, ilkeler ve Politikalar } \\
\text { 1368. Ormanlar, ... -böcek- ... ile ergonomik faktörler dikkate alınarak işletilecek, korunacak ve geliştirilecektir. } \\
\text { 1377. ..... Zararlı böcek ve hastalıklarla mücadelede, biyolojik metodlara ağırlık verilecektir. } \\
\text { 1381. ... zararlı böcek ve hastalıklarla mücadele ve ... tüm ormancılık faaliyetlerinde sağlık ve etkinlik açısından uzaktan algılama } \\
\text { yöntemlerinin kullanımına ağırlık verilecektir. }\end{array}$ \\
\hline IX & $\begin{array}{l}\text { 7. Temel Amaçlar: Gelişme Eksenleri } \\
\text { 7.1. Rekabet Gücünün Artırılması } \\
\text { 7.1.9. Tarımsal Yapının Etkinleştirilmesi } \\
\text { 508. Doğal orman ekosistemini; başta yangınlar ve zararlılar olmak üzere çeşitli faktörlere karşı, .... çok amaçlı ve verimli şekilde } \\
\text { yönetilmesi amaçlanmaktadır. }\end{array}$ \\
\hline $\mathrm{X}$ & $\begin{array}{l}\text { 2. PLANIN HEDEFLERI VE POLITIKALARI } \\
\text { 2.2. YENILIKÇI ÜRETIM, ISTIKRARLI YÜKSEK BÜYÜME } \\
\text { 2.2.15. Tarım ve Gıda } \\
\text { a. Durum Analizi } \\
\text { 755. ..... zararlı böcek ve hastalıklarla mücadelede kimyasal yöntemler azaltılarak biyolojik mücadele yöntemine ağırlık verilmiştir. } \\
\text { b. Amaç ve Hedefler } \\
\text { 775. Ormancılıkta .... hastalık ve zararlılara karşı mücadele kapasitesi geliştirilecek, ..... }\end{array}$ \\
\hline
\end{tabular}


Kalkınma planlarına altık olan ormancılık özel ihtisas komisyonu (ÖiK) raporları incelendiğinde (Çizelge 2), IV-X. dönem raporlarının tümünde B1, B2 ve B4 kapsamındaki hususlara rastlanırken, B7 ve B8 en az yer bulan hususlar olarak dikkat çekmektedir.

Çizelge 2: Ormancılık özel ihtisas komisyonu raporlarında ormanlardaki böcek ve benzeri zararlılara ilişkin durum

\begin{tabular}{|c|c|c|c|c|c|c|c|c|c|c|c|}
\hline Plan Dönemi & Yıllar & B1 & B2 & B3 & B4 & B5 & B6 & B7 & B8 & B9 & B10 \\
\hline I, II ve III & (1963-1977) & & & & & & & & & & \\
\hline IV & (1979-1983) & $x$ & $x$ & $x$ & $x$ & & $x$ & $x$ & $x$ & $x$ & \\
\hline V & (1984-1988) & $x$ & $x$ & $x$ & $x$ & $x$ & $x$ & & $x$ & $x$ & \\
\hline VI & $(1990-1994)$ & $x$ & $x$ & $x$ & $x$ & $x$ & $x$ & & & $x$ & $x$ \\
\hline VII & $(1996-2000)$ & $x$ & $x$ & $x$ & $x$ & $x$ & $x$ & & & $x$ & $x$ \\
\hline VIII & (2001-2005) & $x$ & $x$ & $x$ & $x$ & $x$ & $x$ & & & $x$ & $x$ \\
\hline IX & $(2007-2013)$ & $x$ & $x$ & & $x$ & & & $x$ & & $x$ & \\
\hline $\mathrm{x}$ & (2014-2018) & $x$ & $\mathrm{x}$ & & $x$ & & & & & & \\
\hline
\end{tabular}

B1-Zararı böceklerin ormana ve orman ürünlerine zarar veren faktörler arasında sayılması ve başlıca türlerin belirtilmesi

B2-Zararlı böceklerle mücadelede kullanılan mücadele yöntemleri

B3- Böcek tahribatına maruz orman alanı varlığı

B4- Böcek zararlılarıla mücadele edilen orman alanı varlığı ve/veya harcama tutarları

B5- Böcek tahribatına maruz ağaç serveti ve ürün miktarı

B6- Böcek zararlılarıyla mücadelede kullanılan örgüt yapısına ilişkin tespit ve öneriler

B7- Farklı mücadele imkânları (Havadan mücadele, uydu imkânlarından istifade vb.)

B8- Mücadelede kullanılan kaynakların tahsis zamanında yaşanan sorunlar

B9- Zararlı böcek ve hastalıklarla mücadele yatırım programı ve hedefleri

B10- Böcek zararının ekonomik boyutuna ilişkin tespit ve değerlendirmeler

Kaynak: Anonim 1977, Anonim 1985b, Anonim 1990a, Anonim 1995, Anonim 2001, Anonim 2007, Anonim 2014

Öik raporlarında böcek zararının ekonomik boyutuna ilişkin tespit ve değerlendirmelere (B10) ise sadece VI, VII ve VIII. dönem raporlarında rastlanmaktadır. Her üç raporda neredeyse birebir aynı tespit ve değerlendirmeler yer almaktadır. IX ve X. KP dönemi ÖiK raporlarında ise böcek zararlarına ilişkin nispeten daha az ayrıntıya yer verildiği görülmektedir. İlgili Öik raporlarının hazırlanma sürecinde öncekilerden farklı olarak içerik (sayfa) sınırlandırmasına gidilmiş olmasının bunda etkili olması muhtemeldir.

Türkiye Ulusal Ormancılık Programı'nda (Anonim 2004a) ise, ormanları tehdit eden böceklerle mücadele sürecinde kullanılan mücadele yöntemleri ile orman teşkilatının kurumsal ve finansal kapasitesinin güçlendirilmesine ilişkin önerilere yer verilmiştir. Yine OGM yıllık faaliyet raporlarında (Anonim 2003, Anonim 2017) ise böcekle mücadelede kullanılan yöntemler ile mücadele yapılan alan ve harcama rakamlarına yer verilmiştir.

\subsection{Akademik Çalışmalar}

Türkiye ormancılığında böcek zararlarının ormanlara ve orman yönetim sürecine yönelik ekonomik etkileri literatürde genel olarak; ağaçlandırma ve tamamlayıcı ağaçlandırma masraflarının yükselmesi, istihsal masraflarının artması, böcek zararına maruz ürün fiyatlarının düşmesi ve ekonomik kayıplar doğurması, zarara maruz ağaçlarda artım kayıplarının oluşması ya da büyümenin azalması, amenajman planlarının uygulanmasının zorlaşması ve işletme idaresinin bozulması ve ağaçlardaki kurumalar sonucunda meşcere bütünlüğünün bozulması (Çanakçıŏlu 1989, Özder ve Keskinalemdar 1992, Sertkaya 2010) başlıkları altında toplanmaktadır. Bu bağlamda Türkiye ormanlarında böcek zararlarının ekonomik etkilerini doğrudan ve dolaylı şekilde ele alan akademik çalışmalara ilişkin özet bilgiler tarihsel sırayla Çizelge 3'te sunulmuştur. 
Çizelge 3: Ülkemizdeki böcek ve benzeri zararlıların ekonomik etkilerine ilişkin akademik çalışmalar

\begin{tabular}{|c|c|c|c|}
\hline Kaynak & İçerik & A & B \\
\hline 1. Defne (1954) & $\begin{array}{l}\text { Ips sexdentatus zararının ekonomik sonuçları kapsamında; mücadele masrafları, ağaç serveti } \\
\text { ve ürün değer kayıplarının sayısal olarak ortaya konması }\end{array}$ & $\mathrm{X}$ & \\
\hline 2. Berkel ve ark. (1965) & $\begin{array}{l}\text { Mavi renklemenin } \\
\text { tomruk ve kerestedeki değer kaybı (\%14-50) tespiti }\end{array}$ & & $\mathrm{x}$ \\
\hline 3. Çanakçıŏlu (1989) & Böcek zararlarının muhtemel (ekonomik) etki türlerinin (fiyat vb.) sıralanması & & $\mathrm{x}$ \\
\hline 4. Çanakçıŏlu (1993) & Yerel düzeyde böcek zararına maruz orman alanı ve ağaç serveti değerlerinin sunumu & & $\mathrm{X}$ \\
\hline $\begin{array}{l}\text { 5. Özder ve Keskinalemdar } \\
\text { (1992) }\end{array}$ & $\begin{array}{l}\text { Orman amenajmanıyla olan ilişkisi kapsamında böcek kaynaklı muhtemel etki türlerine (artım } \\
\text { kaybı, amenajman planlarının etkilenmesi vb.) değinilmesi }\end{array}$ & & $\mathrm{x}$ \\
\hline 6. Toper Kaygın (2003) & $\begin{array}{l}\text { Göknar kabuk böceklerinin ekonomik önemine ilişkin sadece böcek zararına maruz ağaç serveti } \\
\text { ve ürün miktarları }\left(\mathrm{m}^{3}\right) \text { ile alan büyüklüklerine (ha) değinilmesi }\end{array}$ & & $\mathrm{x}$ \\
\hline 7. Yazıcı ve Yalçın (2005) & $\begin{array}{l}\text { Artvin OBM'de; böcekle mücadele yöntemleri ve mücadele yapılan alan büyüklüğü, zarara } \\
\text { maruz ağaç serveti, mücadele maliyetleri vb. sunumu }\end{array}$ & & $\mathrm{x}$ \\
\hline 8. Dikilitaş ve Öztürk (2005) & $\begin{array}{l}\text { Artvin OBM'de pazarlama sürecinde karşılaşılan sorunlar ile I.typographus ve I. sexdentatus'un } \\
\text { tomruk piyasasına etkileriyle ilgili gözlem ve tespitlerin sunumu }\end{array}$ & & $\mathrm{X}$ \\
\hline 9. Akyol ve Tolunay (2006) & $\begin{array}{l}\text { Türkiye'de sürdürülebilir orman yönetimini etkileyen bir faktörlerden biri olarak böcek } \\
\text { zararının, zarara maruz alan ve ağaç serveti değerleri olarak dikkate alınması }\end{array}$ & & $\mathrm{X}$ \\
\hline 10. Aytar (2006) & $\begin{array}{l}\text { Pozantı Orman İşletmesindeki böcek zararları kapsamında; böcek zararına maruz ürün miktarı } \\
\text { ve böcekle mücadele harcamalarının dikkate alınması }\end{array}$ & & $\mathrm{x}$ \\
\hline 11. Kantay ve Köse (2008) & Depolarda çürüklük, böcek zararı vb. ekonomik kayıpların oluşumuna ilişkin tespitler & & $\mathrm{x}$ \\
\hline 12. Öztürk ve ark. (2008) & $\begin{array}{l}\text { Artvin OBM'de böceklerin tomruk satışlarına etkisine yönelik zararın muhammen bedel } \\
\text { artırma oranlarına etkisi ve buna bağlı ortaya çıkan gelir kaybı potansiyelinin tesbiti }\end{array}$ & $\mathrm{x}$ & \\
\hline 13. Yilmaz ve ark. (2009) & $\begin{array}{l}\text { Orman teşkilatı çalışanlarının "Ekonomik Zarar Düzeyi" ve "Ekonomik Zarar Eşikleri" hakkında } \\
\text { bilgi eksikliğine sahip oldukları sonucuna ulaşılması }\end{array}$ & & $\mathrm{x}$ \\
\hline 14. Dikilitaş ve Öztürk (2010) & Artvin OBM satışlarında böcek zararına bağlı olağanüstü üretimlerin etkisi & & $\mathrm{X}$ \\
\hline 15. Sertkaya (2010) & $\begin{array}{l}\text { AB ve Türkiye'de kabuk böceklerinden kaynaklı olağanüstü üretimlerin işletmeler için } \\
\text { ekonomik kayıplar doğuracağına ilişkin değerlendirmeler }\end{array}$ & & $\mathrm{X}$ \\
\hline 16. Komut ve ark. (2010) & Depolarda ürünlerin böcek tahribatı ve çürüklüğe maruz kalmasına ilişkin tespitler & & $\mathrm{X}$ \\
\hline 17. Öztürk ve ark. (2011) & $\begin{array}{l}\text { Artvin yöresinde tomruk satış fiyatını etkileyen ve böcek zararını da içeren değişkenler için } \\
\text { doğrusal bir fiyat modeli geliştirilmesi }\end{array}$ & $\mathrm{X}$ & \\
\hline 18. Güngör ve Daşdemir (2014) & $\begin{array}{l}\text { Bartın yöresi ormanlarında büyük göknar kabuk böceği (Pityokteines curvidens Germ.) } \\
\text { zararlısının ekonomik etkilerinin belirlenmesine yönelik analizler ve sonuçları }\end{array}$ & $\mathrm{x}$ & \\
\hline 19. Saraçoğlu (2014) & Böcekli odunların enerji amaçı kullanım imkânlarının literatürle değerlendirilmesi & & $\mathrm{X}$ \\
\hline 20. Çatal ve Carus (2017) & Böcek zararını da içine alan olağanüstü etaların büyüklükleri itibariyle sınıflandırılması & & $\mathrm{x}$ \\
\hline
\end{tabular}

A: Doğrudan ilişkili; B: Dolaylı ilişkili

\subsubsection{Doğrudan ilişkili Çalışmalar}

Böceklerle mücadele harcamaları ve fiziksel zararların boyutlarına ilişkin tespitleri içeren çalışmalar bir kenara bırakılırsa Defne (1954) tarafından kaleme alınan makale, böcek zararlarının ekonomik etkilerine ilişkin tespit ve değerlendirmelerin yer aldığı Türkiye'deki ilk çalışma olarak kabul edilebilir (Çizelge 3). Ips sexdentatus'un Çoruh Ormanlarındaki* zararını ele alan çalışmada ekonomik ve fiziki zarar çeşitleri ve sonuçları;

- Zararın başlangıcından beri gerçekleşen 127 bin liralık mücadele masrafları,

- Mücadele kapsamında hasat edilen dikili kabuklu gövde hacmi değer kaybı,

\footnotetext{
${ }^{*}$ Araştırma alanı makalede bu șekilde adlandırılmıstır.
}

- Hesaplamaya konu edilemeyen arazinin eski haline getirilmesinin maliyeti,

- Borçka'da böcekli ladin kerestesinde oluşan toplam kıymet kaybı (631 100 lira) ve

- Karışık ormanlarda toplamda $416000 \mathrm{~m}^{3}$ seviyesinde servet kaybı

olarak ifade edilmektedir.

Artvin OBM ormanlarında zarar yapan kabuk böceklerinin ladin tomruk açık artırmalı satışları üzerine etkisini belirlemeye yönelik Öztürk ve ark. (2008) tarafından gerçekleştirilen araştırmada ise, satış deposunda bulunan ladin tomruk istifleri böcek zararına bağlı olarak; hasarsız, arz hasarlı ve çok hasarlı şeklinde üç gruba ayrılarak, her 
bir gruba giren partilerin (istiflerin) muhammen bedel artırma oranları karşılaştırılmıştır. Sonuçta, üç grup arasında muhammen bedel artırma oranı (MBAO) bakımından istatistiki olarak anlamlı ölçüde bir fark bulunmuştur. Hasarsız istif satışlarındaki ortalama MBAO'nun, az hasarlı ve çok hasarlı istiflerinkinden istatistikî olarak anlamlı derecede yüksek olduğu; buna mukabil az hasarlı ve çok hasarlı istifler arasında MBAO bakımından anlamlı bir fark olmadığı belirlenmiştir. MBAO'lardaki bu farklııktan kaynaklı, Artvin OBM'de 2002-2007 yılları arasında 2 milyon Dolarlık bir satış geliri kaybı potansiyeli tahmin edilmiştir.

Öztürk ve ark. (2011) tarafından hazırlanan bir başka çalışmada ise böcek zararına maruz tomruklarda zarar ile satış fiyatı arasındaki ilişki araştırıımışır. Bu amaçla ladin tomruk satış fiyatı üzerinde; "açık artırmada pey süren müşteri sayısı", "hasat yılı" ve "muhammen bedel" gibi değişkenlerle birlikte "böcek zararı"nın etkisinin olup olmadığını tespit emek üzere Artvin Devlet Orman İşletmesi (DOi) satış depolarında böcek zararına farklı düzeylerde maruz kalmış ve açık artırmalı satışa çıkarılmış toplam 111 adet tomruk istifi örnek olarak alınmıştır. ilgili değişkenlerle kurulan doğrusal fiyat modeli sonucunda böcek zararına maruz kalmış tomrukların satış fiyatı \%80 oranında açıklanmıştır. Modelden elde edilen sonuçlara göre, böcek zararı düzeyi değişkeni ile satış fiyatı arasında negatif yönlü anlamlı bir ilişkinin var olduğu tespit edilmiştir. Buna göre, diğer değişkenler sabitken zarar düzeyi değişkeni katsayı değeri olan -5.663, tomruk zarar düzeyi grubunun bir birim artmasının, yuvarlak odun satış fiyatını $5.663 \mathrm{TL} / \mathrm{m}^{3}$ düşüreceği ve bu nedenle pey süren müşterilerin tomruk zarar düzeyindeki artışı dikkate alarak, rezerv fiyatlarını daha düşük tutacağı ve böylece tomruk satış fiyatının daha düşük oluşacağı belirtilmiştir.

Son olarak Güngör ve Daşdemir (2014) tarafından hazırlanan ve Bartın yöresi ormanlarında büyük göknar kabuk böceği (Pityokteines curvidens Germ.) zararlısının ekonomik etkilerini belirlemeyi amaçlayan çalışmada, böcek zararına maruz olan ve olmayan satış istifleri esas alınarak, 2008-2012 yılları arasındaki açık artırmalı satışlar, satış miktarları ve fiyatlarındaki değişimler itibariyle incelenmiştir. Buna göre böcek hasarından kaynaklı satış geliri kaybı ile böcekle mücadele giderleri toplandığında 449 bin TL/yıl düzeyinde bir parasal kaybının söz konusu olduğu ifade edilmiştir.

\subsubsection{Dolaylı ilişkili Çalışmalar}

Türkiye'de böceklerin ormanlarda meydana getirdiği zararlar ve bunların etkilerinin ele alındığı çalışmalar incelendiğinde (Çizelge 3), bir önceki bölümde bahsedilen doğrudan ilişkili çalışmalar hariç bu çalışmaların büyük bir kısmında zarar kaynaklı etkilerin ekonomik değil fiziksel boyutlarıyla ele alındığı ya da ekonomik etkilere ilişkin genel tespit ve değerlendirmelerle yetinildiği görülmektedir. Nitekim Ips sexdentatus, Dendroctonus micans ve Ips typographus kabuk böceklerinden kaynaklı zararlara ilişkin tespit ve değerlendirmelerin yer aldığı çalışmalarda (Çanakçıoğlu 1993, Özder ve Keskinalemdar 1992) ağırlıklı olarak farklı zaman dilimlerinde zarara maruz olan orman alanı ve ağaç serveti büyüklüğü değerleri üzerinde durulurken, benzer yaklaşıma göknar ağaçlarında zarar yapan böcek türleri ve ekonomik önemlerini belirlemek amacıyla ele alınan çalışmada da rastlanmaktadır (Toper Kaygın 2003).

Öte yandan, Ülkemiz ormancılığında zaman zaman olağanüstü üretimler (etalar) dolaylı da olsa böcek zararlarının ekonomik etkileri bağlamında kısmi olarak ele alınmıştır. Örneğin Özder ve Keskinalemdar (1992) tarafından Karadeniz Bölgesi doğu ladini ormanlarında farklı yer ve zamanlarda görülen kabuk böceklerinin neden olduğu zararların büyüklüğüne atfen Şavşat Orman İşletmesi'nde 1990-1991 yıllarında planlanan üretimin yaklaşık \%90'ı düzeyinde böcek zararından kaynaklı beklenmedik üretim yapıldığı ifade edilmektedir. Yine Çatal ve Carus (2017) tarafından orman bölge müdürlüklerinin yıllık ortalama olağanüstü hasılat etalarına göre gruplandırıldığı araştırmada, ülke genelinde böcek zararının yedi olağanüstü hasılat eta çeşidi içinde \%14'lük oranla dördüncü, sadece insan etkisi olmayan etalar içinde ise \%30'luk oranla ikinci sırada yer aldığı ifade edilmiştir. Aytar (2006)'ın çalışmasında ise böcek zararı kaynaklı olağanüstü üretim miktarları yanında böcek türleri itibariyle yapılan mücadele harcamalarına da yer verilmiştir.

Yine böcek zararı kaynaklı olağanüstü üretimlerin müşterilerin ürünlere yönelik algısını ve talebini olumsuz 
yönde etkilediğine ilişkin gözlem ve tespitler de söz konusudur. Dikilitaş ve Öztürk (2005)'ün bildirisinde, Artvin OBM'de böceklerin arız olduğu doğu ladini ağaçlarının olağanüstü üretime konu edildiği ve zarara maruz tomrukların pazarlamasında ciddi bir imaj sorunu oluştuğu, müşteri taleplerinin ve dolayısıyla tomruk satış fiyatlarının olumsuz yönde etkilendiği ve sonuçta piyasada arz fazlası ve depolarda stok artışı olduğuna ilişkin tespitler söz konusudur (Dikilitaş ve Öztürk 2005, Dikilitaş ve Öztürk 2010).

Özetle farklı amaçlarla ele alınan ve böcek zararı kaynaklı olağanüstü üretimlere vurgu yapılan çalışmalarda ekonomik etkilere dolaylı olarak değinilirken, fiziksel etkiler öne çıkarılmış, böcekle mücadele harcamaları ile imaja bağıı taleplerde görülen düşüşler ve piyasalarda arz fazlası oluşumuna ilişkin genel nitelikli gözlemlere yer verilmiştir.

Öte yandan gözlem ve incelemelere bağlı olarak böcek zararlarının etkileri; fiziksel, yönetsel ve ekonomik boyutlar bağlamında da irdelenmiştir. Örneğin Yazıcı ve Yalçın (2005)'nın bildirisinde korunan alan olarak Artvin Hatila Milli Parkında böcekle mücadelede çeşitli idari sorunlarla karşılaşıldığı, arazi şartlarının olumsuzluğunun mücadele maliyetlerini arttırdığı ve köylülerle orman teşkilatı arasında birim fiyat konusunda anlaşmazlıkların yaşandığına ilişkin tespitlere yer verilmiştir. Akyol ve Tolunay (2006)'ın çalışmalarında, böcek zararları sürdürülebilir orman yönetimini etkileyen bir faktör olarak alınmasına rağmen, etkinin düzeyi sadece zarar gören orman alanı (ha) ve ağaç serveti miktarı $\left(\mathrm{m}^{3}\right)$ üzerinden değerlendirmeye konu edilmiştir.

Yılmaz ve ark. (2009) tarafından yürütülen araştırma projesi raporunda, Orman Zararlılarıyla Mücadele (OZM) Şube Müdürlüğü uzmanlarının Entegre Zararlı Yönetimi (EZY) konusundaki temel bilgilere sahip olmalarına rağmen, "Ekonomik Zarar Düzeyleri" ve "Ekonomik Zarar Eşikleri" gibi konularda bilgi eksikliği yaşadıkları ifade edilmektedir.

Saraçoğlu (2014) tarafından böcek zararına maruz odunların enerji sektöründe kullanılabilirliği literatüre bağlı olarak ele alınmış ve böcek tahribatının ekonomik sonuçlarını da içeren etkileri Türkiye ve Kanada'dan örneklerle değerlendirmeye konu edilmiştir. Sonuçta, Türkiye'de orman bakım ve hasat çalışmaları atıklarıyla birlikte kabuk böcekleri tarafından zarara uğratılan ağaçların da kurulacak pelet ve biyokütle ısı ve güç santrallerinde kullanılabileceği, böylece fosil yakıt bağımlıı̆ı̆ının azaltılarak yeşil enerjiye dayalı teknoloji ile on binlerce insana istihdam sağlanabileceği ifade edilmektedir.

Depolanan odun kökenli ürünlerdeki böcek, mantar vb. zararlarını konu alan çalışmaların bazılarında zararlıların ekonomik etkileri dolaylı da olsa ele alınmıştır. Örneğin, tomruk ve kerestedeki mavileşmenin ürün kalite ve fiyatı üzerinde düşürücü etki yaptığı ve bu etkinin de literatüre bağlı olarak \%14-50 arasında bir değer kaybına neden olduğu (Berkel ve ark. 1965), orman işletmelerinin depolarında bekletilen ürünlerde; renk değişiklikleri, çatlaklar, mikroorganizma tahribatı, böcek tahribatı ve çürüklük gibi faktörler ile kalite ve değer kayıpları yaşandığı ancak bu kayıpların maliyetlerine ilişkin yeterli bilgi olmadığı (Kantay ve Köse 2008, Komut ve ark. 2010) ifade edilmektedir.

\section{DiĞER ÜLKELERIN ORMANCILIĞINDA ZARARLI BÖCEKLERIN EKONOMIK ETKILERI}

$\mathrm{Bu}$ araştırma kapsamında elde edilen derlemeler hariç yurt dışındaki akademik çalışma ve raporların tamamında böcek zararının ekonomik etkileri doğrudan ele alınmıştır (Çizelge 4). 
Çizelge 4: Diğer ülkelerdeki böcek ve benzeri zararlıların ekonomik etkilerine ilişkin akademik çalışmalar ve raporlar

\begin{tabular}{|c|c|c|}
\hline No & Kaynak & İçerik \\
\hline 1. & Anonim (1991) & Böcek zararının piyasadaki yıkıcı etkisinden kaynaklı net ekonomik refah etkisi tahmini \\
\hline 2. & Holmes (1991) & ABD'de böcek zararı sonucu odun piyasasında gerçekleşen net ekonomik refah değişimi \\
\hline 3. & Rosenberg ve Smith (1997) & $\begin{array}{l}\text { Orman böcek zararlarının pazarlamaya konu olmayan ekonomik etkilerinin ölçümünü konu alan } 15 \\
\text { araştırmanın sonuçlarının özeti }\end{array}$ \\
\hline 4. & O'Neill ve Evans (1999) & Böcek zararı kontrol maliyetlerinin kabul edilebilirliğinin maliyet etkinlik analizi ile incelenmesi \\
\hline 5. & Wallner (1997) & ABD'de Gypsy moth zararlısının ormanlardaki ekonomik etkilerinin maliyet hesabı \\
\hline 6. & Tkacz ve ark. (1998) & ABD'de doğal olmayan zararlıların tomruklardaki zararlı risk potansiyelinin belirlenmesi \\
\hline 7. & $\begin{array}{l}\text { Lyytikäinen }- \text { Saarenmaa } \\
\text { (2003) }\end{array}$ & $\begin{array}{l}\text { Finlandiya'da Diprion pini salgınının sarıçamlarda ekonomik zararının hesaplanmasında; ortalama hacim } \\
\left(\mathrm{m}^{3} / \mathrm{ha}\right) \text {, ortalama yıllık hacim artımı, böcek yoğunluğu ve tomruk piyasa değerinden istifade edilmesi }\end{array}$ \\
\hline 8. & Bigsby ve ark. (2003) & $\begin{array}{l}\text { ABD'de istilacı türlerin ekonomik etkilerinin; doğrudan, dolaylı, pazar ve pazar dışı değerlerden oluşan } \\
\text { bir ekonomik etki matrisi ile tahmini }\end{array}$ \\
\hline 9. & Downing ve O’Brien (2004) & $\begin{array}{l}\text { Kuzey Amerika egzotik orman zararlıları bilgi sistemini oluşturmak için ekonomik etki potansiyelinin } 7 \\
\text { farklı duruma bağlı toplam ekonomik etki sayısal skorunun hesaplanması }\end{array}$ \\
\hline 10. & Born ve ark. (2005) & Biyolojik istilalara ilişkin literatürdeki 23 adet ekonomik kapsamlı çalışmanın incelenmesi \\
\hline 11. & Franklin ve Grégoire (2004) & $\begin{array}{l}\text { Belçika'da Ips typograhus istilasına ilişkin 1988-1996 yılları arasındaki } 10000 \text { satış dosyasının incelenmesi } \\
\text { ve anket uygulaması }\end{array}$ \\
\hline 12. & Holmes ve ark. (2006) & $\begin{array}{l}\text { Kuzeydoğu New Jersey'de ekzotik bir orman böceğinin ev sahiplerine yönelik neden olduğu ekonomik } \\
\text { zararların hedonic mülkiyet değeri yöntemi tahmini }\end{array}$ \\
\hline 13. & Lysak ve Ross (2006) & $\begin{array}{l}\text { Sitka ladini meşcerelerinde kabuk biti zararı ile meşcere ve yetişme ortamı karakteristikleri arasındaki } \\
\text { ilişkinin incelenmesi }\end{array}$ \\
\hline 14. & Gatto ve ark. (2008) & $\begin{array}{l}\text { Fayda Maliyet Analizi kullanılarak çamlarda Thaumetopoea pityocampa'ya karşı zararlı yönetimi } \\
\text { uygulanması ve senaryolara göre özel ve sosyal karlılıkların tahmin edilmesi }\end{array}$ \\
\hline 15. & Rosenberger ve ark. (2012) & $\begin{array}{l}\text { Orman böcek zararlılarının pazarı olmayan (fiyatlandırılması zor olan) ekonomik etkilerini konu edinen } \\
\text { araştırmaların sunumu }\end{array}$ \\
\hline 16. & Rosenberger ve ark. (2013) & $\begin{array}{l}\text { Colorado'da Rocky Moutain Milli Parkı'nda dağ çam böcek salgınından kaynaklanan rekreasyonel zararın } \\
\text { ikincil kaynaklardan elde edilen veriler kullanılarak fayda transferi yöntemiyle tahmin edilmesi }\end{array}$ \\
\hline 17. & Cameron ve ark. (2018) & $\begin{array}{l}\text { Avustralya'da 1952-2014 arası çam ağaçlandırmalarında yaşanan salgının maliyetinin Net Bugünkü Değer } \\
\text { Yöntemi ile tahmin edilmesi }\end{array}$ \\
\hline 18. & Arnberger ve ark. (2018) & $\begin{array}{l}\text { Ayrık Seçim Modeli kullanılarak böcek etkisine maruz kalmış orman rekreasyon alanlarında ziyaretçilerin } \\
\text { bundan etkilenme durumlarının belirlenmesi }\end{array}$ \\
\hline & Ivantsova ve ark. (2019) & $\begin{array}{l}\text { Avrupa ülkeleri, ABD, Kanada ve Rusya'da bulunan boreal ormanlardaki orman zararlıları ile ilgili } \\
\text { araştırmaların sunumu }\end{array}$ \\
\hline
\end{tabular}

\subsection{Orman Ekosistem Hizmetleri}

Yurt dışında yürütülen çalışmalarda zararlı böceklerin ekonomik etkileri ağırlıklı olarak orman ekosistem hizmetleri kapsamında ve farklı etki çeşitlerini içerecek şekilde nispeten geniş bir bakış açısıyla ele alınmaktadır. Bu bağlamda Rosenberg ve Smith (1997) ile Rosenberg ve ark. (2012) tarafindan hazırlanan raporlarda, orman zararlısı böceklerin fiyatlandırılmasındaki zorluklardan dolayı pazarlamaya konu edilemeyen ürünlere (orman ekosistem hizmetlerine) yönelik ekonomik etkilerinin ölçümünü konu alan 22 farklı araştırmanın (Payne ve ark. 1973, Wickman ve ark. 1975, Michalson 1975, Moeller ve ark. 1977, Leuschner ve Young 1978, Walsh ve Olienyk 1981, Walsh ve ark. 1981a, Walsh ve ark. 1981b, Loomis ve Walsh 1988, Walsh ve ark. 1989, Walsh ve ark. 1990, Jakus ve Smith 1991, Haefele ve ark. 1992, Miller ve Lindsay 1993, Holmes ve Kramer 1996, Thompson ve ark. 1999, Haefele ve Loomis 2001, Kramer ve ark. 2003, Asaro ve ark. 2006, Holmes ve ark. 2006, Huggett ve ark. 2008, Price ve ark. 2010) sonuçları özetlenmiştir. Böcek zararları ve etkilerini ele alan bahse konu raporda; pazarlamaya konu edilmeyen mal ve hizmetlerin ekonomik değerlendirmelerinde kullanılan yöntemler ve değerlendirmeye konu edilen değerler teorik olarak açıklanmıştır. İrdelenen çalışmalar yardımıyla böcek zararlarının hesaplanmasına yönelik çalışmalar; arazi kullanımları itibariyle şehir, şehir / yabanıl arazi arakesiti ve yabanıl alanlarda gerçekleştirilen çalışmalar, ilgi çıkar grubu itibariyle; genel toplum kesimleri, konut sahipleri, arazi yöneticileri, emlakçılar ve rekreasyonistler, ekonomik açıdan tanımlanan ve ölçülen değerler olarak; 
estetik, pasif kullanım, mülkiyet, rekreasyon ve toplam değer, pazarlamaya konu edilmeyen mal ve hizmetlerin ekonomik değerlendirmesinde kullanılan yöntemler olarak; koşullu değerlendirme, hedonik fiyatlama, seyahat maliyeti ve diğer yöntemler ve ekonomik değerlendirmede böceğin ekonomik etkisini gösteren değişkenler olarak; ağaç sayısı, böcek varlığı, ağaç boyutu, görünür zarar ve diğer değişkenler şeklinde sıralanmaktadır. Böylece çalışmada, ormandaki zararlı böceklerin pazarlamaya konu edilmeyen ekonomik etkilerine ilişkin araştırmalar gerek teorik ve gerekse uygulama sonuçları bağlamında özlü bir şekilde ortaya konmaktadır. Bu rapor kapsamında yapılan literatür incelemeleri, ormanlarda zarar yapan böceklerin sağlıklı bir ormanın sunduğu pazarı olmayan mal ve hizmet faydalarını yani ekosistem hizmetlerini önemli ölçüde etkilediği tezini desteklemektedir.

Ormanların ekosistem hizmetleri kapsamında böcek zararlarının doğurduğu ekonomik etkilere ilişkin araştırma konularından biri de ormanların yakınında bulunan konutların (mülklerin) değerinde görülen değişmelerdir. Holmes ve ark. (2006) tarafından Kuzeydoğu New Jersey'de ekzotik bir orman böceğinin (hemlock woolly adelgid) etkisini belirlemek amacıyla ele alınan çalışmada, hedonik mülkiyet değeri yöntemi ile tsugaların sağlığının mülkiyet değerleri üzerindeki etkisi tahmin edilmiştir. Araştırma alanında 1992-2002 yılları arasındaki 3.379 adet iskâna ayrılmış mülk satışına ilişkin verilerden (parsel büyüklüğü, fiyatı, otoyola uzaklık vb.) istifade edilmiş ve sonuçta tsugaların sağlığı ile iskâna ayrılmış mülklerin değerleri arasında istatistiki olarak önemli bir ilişki bulunmuştur. Ayrıca tsugaların zayıflamasından doğan bazı yaygın etkiler komşu mülklerde de görülmüştür. Bu sonuçlar, bölgede muhtemel bir kontrol programına olan intiyacı işaret ederken, benzeri yerler açısından önemli bir dayanak olarak yorumlanmıştır.

Benzer şekilde böcek zararlarının doğurduğu etkilerden bir diğeri de zarara konu alanlardaki rekreasyonel faaliyetlerde yaşanması muhtemel değişimlerdir. Arnberger ve ark. (2018) tarafından farklı düzeylerde kabuk böceği salgınına maruz ibreli ormanlarda ziyaretçi tercihleri Ayrık Seçim Modeli kullanılarak araştırımıştır. Sonuçta böcek etkisine maruz rekreasyon alanlarının ziyaretçilerin tercihlerini belirlemede etkili olduğu ve rekreasyon alanlarının bu tarz kabuk böceği etkisine maruz kalmasının, bir taraftan bu alanlara yönelik rekreasyon talebini azaltırken diğer taraftan da turizm gelirleri ile diğer ekosistem hizmetlerinde kayıplara neden olacağı belirtilmiştir.

Yine Rosenber ve ark. (2013) tarafından Rocky Moutain Milli Parkı'nda böcek salgınından kaynaklanan rekreasyonel zararın ikincil kaynaklardan elde edilen veriler kullanılarak fayda transferi yöntemiyle tahmin edilmesinin amaçlandığı çalışmada, rekreasyonel kullanım değerine göre alanda daha büyük değerlere karşılık gelen pasif kullanım değerlerinin (seçenek, varlık vb.) ve kullanım dışı değerlerin dikkate alınmadığı, sadece rekreasyona bağlı muhafazakâr bir zarar tahmini yapıldığ özellikle vurgulanmaktadır.

\subsection{Ekzotik Orman Zararlıları}

Dünya odun hammaddesi ticaretinde görülen artışla birlikte orman zararlıların (böceklerin) yeni ortamlara girme riskini artırmasından dolayı, ekzotik orman zararlılarının küresel düzeyli ekonomik etkileri dikkat çekmeye başlamıştır. Ekzotik zararlıların etkisiyle Amerika Birleşik Devletleri ormanlarında ekolojik ve ekonomik yıkımlara neden olan ciddi salgınlar meydana gelmiştir (Tkacz 2002). Birleşik Devletler Tarım Departmanı Orman Servisi raporunda (Anonim, 1991), Sovyetler Birliği'nden ithal edilen ürünlerdeki ladin kabuk böceklerinden kaynaklanan ekonomik etkinin tahmini için iki senaryo (iy ve kötü) geliştirilmiştir. Bu bağlamda kabuk böceklerinden kaynaklanan yıkıcı etki öncesi piyasa dengesi ve yıkıcı etki sonrası piyasa dengesi arasındaki farklılıktan hareketle potansiyel ekonomik etki bir başka ifadeyle yıkıcı etkiden kaynaklanan net ekonomik refah etkisi tahmin edilmeye çalışılmıştır. Piyasa dengesindeki değişime bağlı üretici ve tüketici rantları dikkate alınarak yapılan hesaplamalarda; Washington ve Oregon'daki ladin ağaçlarının tamamının 7 yıl içinde öleceği kötü senaryosuna göre 1990 fiyatlarıyla 1.5 milyar dolarlık bir zarar ve iyi senaryoda ise ağaçların sadece \% 25'inin 30 yıl içinde öleceği ve 201 milyon dolarlık bir zarar oluşacağı tahmin edilmiştir.

Yine ekzotik zararlı bir böcek olan Gypsy moth'un ekonomik etkilerinin ele alındığı araştırmada (Wallner 
1997) Birleşik Devletlere Sibirya ve Yeni Zelanda'dan gelen ekzotik böceklerin orman kaynaklarına yönelik ekonomik etkileri maliyetler dikkate alınarak hesaplanmış ve en kötü senaryo esas alındığında 1990 yılı fiyatlarıyla söz konusu böceklerin maliyeti 60 milyar dolar olarak tahmin edilmiştir.

Öte yandan, Kuzey Amerika'da yapılan çalışmada (Downing ve O'Brien 2004) olduğu gibi ekzotik orman zararlı riskini belirlerken de zararlarının ekonomik etkilerinden istifade edilmiştir. Çalışmada ekzotik zararlı riskini belirlemede esas alınan dört kriterden (Kuzey Amerika'da bulunma potansiyeli (BP), yayılma potansiyeli (YP), ekonomik etki potansiyeli (EEP) ve çevresel etki potansiyeli (ÇEP)) bir tanesi "ekonomik etki potansiyeli" olmuştur. Bu kriterlerden her biri; zararlının durumuna ve özelliğine göre; yüksek, orta ve düşük riskli olarak ayrılmıştır. En sonunda ise; yüksek risk 3, orta risk 2 ve düşük risk 1 puan ile değerlendirilerek toplam etkinin yani sonuç puanının (SP'nin) sayısal skor olarak şu formül yardımıyla hesaplanabileceği ifade edilmiştir:

$S P=B P$ ve $Y P^{\prime}$ nin düşük puanı $\times$ ÇEP ve EEP'nin yüksek puanı

\subsection{Piyasa Etkileri}

Ormanlardaki böcek zararlarını alansal bazda değerlendiren geleneksel yaklaşımların, piyasa ve ekosisteme ilişkin tüm etkileri dikkate alamadığından hareketle Holmes (1991) tarafından ele alınan çalışmada; orman ekosisteminin bütününde odun üretimine konu meşcerelere yönelik yıkıcı etkiler sonucu oluşan sosyal refahtaki değişikliklerin piyasa düzeyinde analizi gerektirdiği ve böcek salgınları sonucu oluşan net ekonomik refah değişiminin ise şüphe götürmeyecek derecede negatif olduğu sonuçlarına ulaşılmıştır.

Öte yandan, böcek zararlarının ekonomik etkilerinin belirlenmesinde başvurulan yaklaşımlardan biri de böcek salgınlarının orman ağaçlarında neden olduğu büyüme kayıplarına bağlı ekonomik zarar tahminleridir. Bu bağlamda Finlandiya'nın güney batısında Diprion pini salgınından sonra sarıçam ormanlarında meydana gelen büyüme kayıplara ve ağaç ölüm oranlarına bağıı zararların ekonomik değerlerine ilişkin ön tahminler yapmak amacıyla Lyytikäinen - Saarenmaa (2003) tarafından ele alınan çalışmada; zayıf, orta ve yoğun yaprak dökümüne maruz ağaçlardaki çap artımı miktarlarını belirlemek için artım örnekleri alınmış ve akabinde ekonomik zararların hesaplanabilmesi için; ortalama hacim $\left(\mathrm{m}^{3} / \mathrm{ha}\right)$, ortalama yıllık hacim artımı, böcek yoğunluğu ve tomruk piyasa değerinden oluşan dört farklı değişkenden istifade edilmiştir. Sonuçta orta düzey bir salgın sonucunda meydana gelen büyüme kayıplarının ortalama ekonomik değerleri 1994 yılı için $118 €$ /ha olarak tahmin edilmiştir.

Yine Ivantsova ve ark. (2019) tarafından Avrupa ülkeleri, $A B D$, Kanada ve Rusya'da bulunan boreal ormanlardaki orman zararlıları ile ilgili araştırmaların derlendiği makalede, Batı ülkeleri için geçerli olan böcek yönetimi stratejilerinin kurumsal zorluklardan dolayı Rusya'da uygulanmasının kolay olmadığı, ancak istilacı türlerin yönetimine ilişkin Rusya ormancılık sektörünün geleceğinin planlamasında bu tür deneyimlerin faydalı olacağı vurgulanmaktadır. Bu nedenle istilacı orman zararlılarının ekonomik etkilerini analiz etmek için bazı teorik yaklaşımlar mevcut olsa da ormanlarda böceklerin yol açtığı zararlarının analizine ilişkin önemli bir katkının hala mümkün olmadığı ifade edilmektedir.

Öte yandan literatürde ormanlardaki zararlıların önlenmesi ve kontrolüne yönelik geliştirilen EZY programları kapsamında da böcek zararlarının ekonomik etkileri ele alınmaktadır. Örneğin Dendroctonus micans'ın coğrafi yayııışının kontrolü üzerinde yoğunlaşarak, kontrol maliyetlerinin kabul edilebilir olup olmadığını belirlemek ve entegre böcek yönetimi yaklaşımının maliyetlerini tahmin etmek amacıyla ele alınan çalışmada (O'Neill ve Evans 1999), üç alternatifli bir maliyet etkinlik analizi gerçekleştirilmiştir. Alternatifler; hastalıklı odunların taşınmasını önleme ve Rhizopsuz grandis yırtıcısını kullanmaya dayalı mevcut politika, hiç bir şey yapmama ya da böcek yönetim alanına ilişkin yeni bir Dendroctonus micans konrol alanı oluşturma şeklinde sıralanmıştır. Modelin varsayımı ise odun kayıpları açısından ele alındığında kontrol maliyetlerinin istilanın maliyetinden daha az olacağı şeklindedir

Franklin ve Grégoire (2004) tarafından hazırlanan makalede, Belçika'da kamu ormanlarından elde edilen 
hasarlı ağaçların satışından elde edilen verilerin Ips typograhus istilasına ilişkin bilgi elde etmede kullanılıp kullanılamayacağı araştırımıştır. Bu amaçla, 1988-1996 yılları arasındaki 10.000 satış kaydının incelendiği ve böcek zararına maruz kalmış 1.100 satışın tespit edildiği ve bu satışlara ilişkin ağaç türü, odun kalitesi ve silvikültürel uygulamaya ilişkin bilgilerin derlendiği ifade edilmektedir. Verilerin güvenilirliğini test etmek amacıyla yerel ormancılara yapılan anket sonucunda, yerel ormancıların genel olarak zararların tanımlanması ve raporlanmasında yeterli uzmanlığa sahip oldukları, ancak bazen aşırı tahminlerde bulunabildikleri, bu noktada hasarlı ağaçların satışlarına ilişkin kayıtların yeterli olabileceği vurgulanmaktadır.

Birleşik Devletlerde zararlı risk değerlendirmesini konu alan raporda (Tkacz ve ark. 1998) Meksika'dan ithal edilen işlenmemiş çam ve göknar tomruklarının zararlı risk potansiyeli belirlenmeye çalışılmıştır. Çalışmada böceklerin de içinde yer aldığı zararlılar türleri itibariyle bulunma olasılığı ve sonuçlar (ekonomik, çevresel ve sosyal sonuçlar) düşük, orta ve yüksek düzey şeklinde değerlendirilerek zararlı risk potansiyeli elde edilmiştir.

Yine Bigsby ve ark. (2003) tarafından ABD'de gerçekleştirilen proje; istilacı türlerin ekonomik etkilerini de içine alan kapsamlı bir istilacı türler risk yönetimi çatısı oluşturmak ve istilacı tür yönetimiyle ilgili kişi ve kurumları içine alan disiplinler arası ortak bir ağ oluşturmak şeklinde iki temel amaçla ele alınmıştır. Projenin ekonomik boyutu kapsamında; doğrudan, dolaylı, pazara konu ve pazar dışı değerlerin kombinasyonuyla ekonomik etkilerin tanımlanmalarında kullanılabilecek bir ekonomik etki matrisi oluşturulduğu görülmektedir. Söz konusu matris şu şekildedir (Çizelge 5)

Çizelge 5: İstilacı türler ekonomik etki matrisi

\begin{tabular}{llll}
\hline \multicolumn{1}{c}{ Zararlar / Etkiler } & \multicolumn{1}{c}{ Pazar etkileri } & \\
\hline Direk zararlı etkiler & $\bullet$ & Odun kökenli ürünler & Pazar dışı etkiler \\
& $\bullet$ & Zarara / yangına dayanıklı türler & Kentsel peyzaj \\
& $\bullet$ & Kontrol maliyetleri & Yaban hayatı habitatı \\
\hline Dolaylı zararlı etkiler & $\bullet$ & Turizm & \\
& $\bullet$ & Ticari etkiler & Besin döngüsü \\
& $\bullet$ & Yangın zararı & Hidroloji \\
& & & Politik etkiler \\
\hline
\end{tabular}

Ayrıca toplam ekonomik etkinin de aşağıdaki formül (m: olası farklı çıktılar, Yi: neden olunan zararın değeri, Pi: çıktı olasılı̆̆ı) yardımıyla hesaplanacağı ifade edilmektedir:

Toplam Ekonomik Etki $=\sum_{\mathrm{i}=1}^{\mathrm{m}}\left(\mathrm{Y}_{\mathrm{i}} \cdot \mathrm{P}_{\mathrm{i}}\right)$

Lysak ve Ross (2006)' un sitka ladini meşcerelerinde kabuk biti zararı ile meşcere ve yetişme ortamı karakteristikleri arasındaki ilişkinin incelendiği makalede, ağaçlarda tespit edilen kusurlar 0-10 arasındaki puanlamayla ölçüldüğü ve buna göre ortalama 2,8'lik bir kusur oranı belirlendiği ifade edilmekte ve ağaçların en az \% 58'inde zararın söz konusu olduğu tespitinde bulunulmaktadır. Ayrıca zararın miktarı ile okyanusla olan uzaklık ve büyüme oranı arasında pozitif; yükseklik, enlem ve ladin yoğunluğu arasında ise negatif bir korelasyon olduğu ve tüm bu değişkenlerle birlikte dikkate aldığında zarar miktarının \%61'inin açıklandığı belirtilmektedir.

\subsection{Maliyet Etkinliği}

Ormancılıkta böcek zararlarının ekonomik etkilerini belirlemede yaygın şekilde kullanılan yaklaşımlardan biri de böceklerle mücadelede fayda masraf karşılaştırmasına dayalı maliyet etkinliği yaklaşımıdır. Born ve ark. (2005) tarafından biyolojik istilalara ilişkin daha önceden yapılmış olan 23 adet ekonomik kapsamlı çalışmanın ayrıntılı olarak irdelenmesi sonucunda, biyolojik istilaların ekonomik analizinde çoğunlukla fayda masraf yaklaşımından yararlanıldığı, fakat bu yaklaşımın toplam ekonomik değerin tüm unsurlarını (doğrudan ve dolaylı kullanım ile kullanım dışı değerler) kapsamaması ve maliyetlerin parasal karşılıklarının belirlenmesindeki zorluklar ve belirsizliklerin çalışmaların önemli eksiklikleri 
olduğu ifade edilmiştir. Bu nedenle benzer çalışmalarda fayda maliyet yaklaşımı yerine daha önce kullanılmamış olan çok ölçütlü karar verme tekniklerinin uygulanması önerilmiştir.

Gatto ve ark. (2008) tarafından hazırlanan makalede, Portekiz çam ormanlarında Thaumetopoea pityocampa için geliştirilen yönetim stratejilerinin özel ve sosyal karlılığının belirlenmesi amaçlanmış ve bu amaçla FaydaMaliyet Analizinden istifade edilmiştir. Bu kapsamda analizde maliyet unsurları olarak orman rehabilitasyonu masrafları ile insan sağığını tehdidin sosyal maliyeti alınırken, rekreasyon ve karbon tutumu gibi sosyal fayda ve gelirlerin her ikisi de faydalar olarak tanımlanmıştır. Örnek alanda yapılan çalışmanın sonucunda, zararlı yönetimi uygulanmaması durumunda ortaya çıkacak gelir kaybının, özel orman sahipleri için kısa vadede zararlı yönetimi uygulamalarına geçmelerini gerektirecek ölçüde karlı olmadığını göstermiştir. Buna karşılık, zararı yönetimi insanların sağlık risklerini en aza indirdiği ve muhtemel rekreasyon kayıplarını önlediği için sosyal kar elde edildiği belirtilmiştir.

Cameron ve ark. (2018) tarafından hazırlanan makalede ise Avusturalya çam ağaçlandırmalarında 1952 ve 2014 yılları arasında Ulusal Sirex Kontrol Programı kapsamında Sirex kontrolüne ilişkin yapılan harcamalar ile büyük ölçekli ağaç ölümlerinin yaşandığı üç ana salgının etkisinin maliyetleri belirlenmiştir. Farklı iskonto oranları ile Net Bugünkü Değer yönteminden istifade edilmiştir. 1952 baz yılı itibariyle ve $\% 5$ iskonto oranı ile programın ve salgınların maliyeti 34,5 milyon dolar olarak tahmin edilmiştir.

Büyük Britanya'da Dendrocronus micans konusunda yapılan bir çalışmada (Anonim 2004b); böceğin ladin ormanlarındaki etkilerini kontrolde kullanılabilecek senaryolar maliyet etkinliği analizine konu edilmiştir. Bu senaryolardan biri Dendrocronus micans'ın zarar maliyetlerini azaltmak için biyolojik kontrol yöntemini uygulamak, diğeri ise böceğin yeni yayılış sahalarında biyolojik kontrolü kullanarak Lake District, Kent ve Devon bölgelerindeki yayılışını dikkate alan yeni bir sınır oluşturmaktır. Bu amaçla kullanılan model şu şekilde olup;
$\mathrm{C}_{\mathrm{cx}}<\mathrm{p}\left(\mathrm{N}_{\mathrm{x}}\right) \mathrm{X}\left(\mathrm{CN}_{\mathrm{x}}\right)$

burada $\mathrm{C}_{\mathrm{cx}} ; \mathrm{x}$ yılındaki kontrol maliyetlerini, $\mathrm{p}\left(\mathrm{N}_{\mathrm{x}}\right) ; \mathrm{x}$ yılındaki salgın olasılığı ve $\left(\mathrm{CN}_{\mathrm{x}}\right)$ ise $\mathrm{x}$ yılındaki salgın maliyetini ifade etmektedir. Modele göre herhangi bir $x$ yılında yapılan kontrol faaliyetlerinin maliyetinin aynı yıla ilişkin salgın olasılığına bağı olarak ortaya çıkması beklenen salgın maliyetlerinden (zarar ve kontrol önlemleri maliyeti toplamı) daha düşük olması öngörülmektedir. Yapılan analizde maliyetler; odun hasılasındaki azalmadan dolayı Dendrocronus micans istilasının zarar maliyeti ve Dendrocronus micans'ın yayılmasını önlemek için uygulanan kontrol önlemlerinin maliyeti şeklinde iki başlık altında ele alınmaktadır.

\section{SONUÇLAR VE DEĞERLENDIRME}

Türkiye ormanları ve ormancılığında böcek zararlarının etkilerinin ekonomik bakış açısıyla hangi kapsamda ele alındığını ortaya koymak amacıyla yurt içi ve yurt dışındaki bilimsel araştırma ve belgelerin incelenmesi ile elde edilen başlıca sonuçları şu şekilde özetlemek mümkündür:

Türkiye'de böcek zararları ve bu zararların sürdürülebilir orman yönetimi ve işletmeciliği faaliyetlerine etkilerini konu alan çalışmaların çoğunda böceklerin ormanlarımızda önemli miktarlarda ekonomik kayıplara neden olduğuna ya da olacağına ilişkin tespitlere (Sarıkaya ve Avcı 2006, Aksu ve ark. 2014, Toprak 2014) rastlanabilmesine rağmen, bu zararların düzeyinin nası tahmin edileceğine ya da hesaplanacağına ilişkin somut çalışmalar yurt dışındakilerle kıyaslandığında oldukça sınırlıdır.

$\mathrm{Bu}$ bağlamda ekonomik etkiler ormancılıkla ilgili belgelerde ağırlıklı olarak, böceklerle mücadele faaliyetlerine ilişkin orman teşkilatlarınca yapılan harcamalar çerçevesinde ele alınmış ve bu harcamalar böceklerin orman işletmeciliği üzerindeki negatif etkileri olarak değerlendirilmiştir. Bununla birlikte özellikle Artvin ve Bartın yörelerinde böcek zararlarının ekonomik etki ve sonuçlarını doğrudan ele alan akademik çalışmalarda ise zarara maruz orman ürünleri satışlarının orman işletmelerinin gelirlerine etkileri üzerinde durulmuştur. 
Türkiye ormanlarındaki böcek zararlarının ekonomik etkileri konusunda gerek kalkınma planları gerekse Türkiye Ulusal Ormancilık Programı'nda herhangi bir tespit ve değerlendirmeye yer verilmezken, Öik raporları ve OGM yıllık faaliyet raporlarında ise mücadelede kullanılan yöntemler, mücadele yapılan alan büyüklükleri ve harcama tutarlarına ilişkin tespitler bağlamında ekonomik etkilere dolaylı da olsa değinilmiştir. Dolayısıyla ormancılıkla ilgili belgelerde böcek zararlarının ekonomik etkilerinin, gerek etki türü gerekse etkinin belirlenmesi ve sonuçları itibariyle zarara maruz orman alanı büyüklüğü ve böcekle mücadele harcamaları ile sınırlı kaldığı anlaşılmaktadır.

Ülkemiz ormanlarında zarar yapan böcek vb. zararlıların ormanlar ve orman işletmeciliği üzerindeki ekonomik etkilerine ilişkin bulgu, tespit ya da değerlendirmelerin yer aldığı 20 akademik çalışma genel olarak değerlendirildiğinde, dolaylı ilişkili çalışmaların (Çizelge 3'teki $2,3,4,5,6,7,8,9,10,11,13,14,15,16,19$ ve 20 nolu çalışmalar) doğrudan ilişkili olanlara (Çizelge 3'teki 1 , 12,17 ve 18 nolu çalışmalar) nazaran çok daha fazla olduğu görülmektedir. Böcek zararlarının ekonomik etkilerinin dolaylı şekilde ele alındığı çalışmalarda ekonomik etki konusu ağırlıklı olarak böcek zararlarının çeşitleri ile fiziksel etkileri ve böcekle mücadele harcama tutarlarına ilişkin istatistiki verilerin sunumu şeklindedir. Dolayısıyla bahse konu dolaylı ilişkili çalışmaların içeriği genel itibariyle ormancilıkla ilgili belgelerden elde edilen fiziksel zarara maruz ağaç serveti düzeyi ve böcekle mücadele harcamalarına ilişkin verilerle sınırlandırılmıştır.

Bununla birlikte söz konusu ekonomik etkileri doğrudan belirlemeye yönelik amaç ve / veya içeriklere sahip olan dört adet çalışmada ise sadece Artvin ve Bartın yöresi ormanlarındaki ladin ve göknar ağaç türlerinde zarar yapan böceklerin ekonomik etkileri konu edilmiştir. Çalışmalarda belirlenmeye çalışılan ekonomik etkiler ise esas itibariyle zarara maruz odun kökenli ürünlerde ortaya çıkması beklenen değer kaybı ve böcekle mücadele harcamalarının piyasa ölçeğinde belirlenmesine dayandığı ifade edilebilir. Dolayısıyla bu çalışmalarda böcek zararına bağlı odun kökenli ürünlerde meydana gelen değer kaybından kaynaklı fiyat değişimlerinden hareketle, piyasa ölçeğinde bir gelir kaybı tahmini (potansiyeli) yapılmıştır. Ayrıca geliştirilen bir doğrusal regresyon modeli ile de böcek zarar düzeyi ile tomruk satış fiyatları arasındaki ilişki incelenmiştir. Dolayısıyla Türkiye'de böcek zararlarının ekonomik etkisini doğrudan ele alan çalışmaların temel hareket noktası zararın neden olduğu ürün satış fiyatlarındaki değişimlerdir.

Türkiye dışındaki pek çok ülkede ise ormanlar ve orman kaynakları yönetimi bağlamında böcek zararlarının ekonomik etkilerini konu edinen akademik çalışmalarda ve hazırlanan raporlarda, söz konusu etkiler genel olarak orman ekosistem hizmetleri, ekzotik orman zararlıları, piyasa etkileri ve maliyet etkinliğini konu alan doğrudan etkiler olarak öne çıkmaktadır (Çizelge 4). Bu çalışmalardan üç adedinin bu konuda daha önce yapılan ekonomik etkileri konu alan çalışmaları özetleyen derleme niteliğinde çalışmalar (Çizelge 4'teki 10, 15 ve 19 nolu çalışmalar) olduğu, diğer çalışmaların ise ulusal ya da yerel düzeyde belli böcek türlerinin neden olduğu zararların ekonomik etkisini birincil verilere dayalı olarak doğrudan ele alan araştırma çalışmaları (Çizelge 4'teki 1 , $2,3,4,5,6,7,8,9,11,12,13,14,16,17$ ve 18$)$ olduğu görülmektedir. Söz konusu çalışmalarla belirlenen başlıca ekonomik etki çeşitleri arasında; böcekle mücadele için yapılan harcamalar ve maliyet etkinliği, ağaç serveti değeri ve ürünlerin piyasa fiyatı / değerindeki değişimler, rekreasyon değeri, varlık, miras ve seçenek değeri, zarara maruz kalan orman alanlarının yakınındaki konutların değeri vb. öne çıkmaktadır.

Yukarıda sırlanan hususlara ilave olarak yine yurt içi ve yurt dışında hazırlanan ormancılıkla ilgili bilimsel araştırma ve belgelerin incelenmesi sonucunda böcek zararlarının ekonomik etkilerini; piyasa odaklı etkiler / doğrudan etkiler ve piyasa dışı etkiler / dolaylı etkiler olmak üzere iki ana başlık altında toplamak mümkündür (Çizelge 6). 
Çizelge 6. Böcek zararlarının ekonomik etkilerine ilişkin öne çıkan etki türleri

\begin{tabular}{llcc}
\hline & Öne Çıkan Etki Belirleme Yaklaşımı & Yurt İçi & Yurt Dışı \\
\hline & A- Zarar önleme ve zararla mücadele maliyetleri & $\checkmark$ \\
Piyasa Odaklı / Doğrudan & B- Maliyet etkinliği & $\checkmark$ & $\checkmark$ \\
& C- Erken kesim zararı & $\checkmark$ & $\checkmark$ \\
& D- Üretici ve tüketici refahındaki değişim & $\checkmark$ \\
& E- Piyasa fiyatı ve işletme gelirlerine etkisi & $\checkmark$ \\
Piyasa Dışı / Dolaylı & F- Rekreasyon değeri & $\checkmark$ \\
& G- Emlak değeri & $\checkmark$ \\
\hline
\end{tabular}

Çizelge 6 incelendiğinde böcek zararlarının ekonomik etkileri kapsamında öne çıkan sekiz farklı etki belirleme yaklaşımı söz konusu olup, ülkemizde bunlardan sadece iki tanesinin kullanıldığı diğerlerine ilişkin herhangi bir araştırma ya da analize rastlanmadığı görülmektedir. Bu çerçevede Ülkemiz özelinde sadece piyasa odaklı etki belirleme yaklaşımları bağlamında A (Zarar önleme ve zararla mücadele maliyetleri) ve $\mathrm{E}$ (Piyasa fiyatı ve işletme gelirlerine etkisi) bileşenlerine yönelik etki belirleme çalışmaları (Defne 1954, Öztürk ve ark. 2008, Öztürk ve ark. 2011, Güngör ve Daşdemir 2014) mevcut iken , piyasa odaklı etkiler kapsamındaki diğer bileşenler ( $B, C$ ve $D$ ) ile piyasa dışı etkiler kapsamındaki bileşenler $(F, G$ ve $H)$ kapsamında herhangi bir çalışmaya rastlanmamıştır.

Öte yandan, Amerika Birleşik Devletleri ve bazı Avrupa ülkeleri başta olmak üzere yurt dışında böcek zararlarını ya da biyolojik zararlıların orman ekosistemleri üzerindeki etkilerini inceleyen pek çok çalışmada (Walsh ve ark. 1981a, Walsh ve ark. 1981b, Patriquin ve White 2004, Olaussen 2005) söz konusu zararların orman kaynakları yönetimi ya da işletmeciliği faaliyetlerine yönelik etkileri; böcekle mücadele için yapılan harcamalar ve harcamaların etkinliği yanı sıra ağaç serveti değeri, ürünlerin piyasa değeri gibi orman kaynakları yönetimine yönelik etkiler yanında, rekreasyon değeri, zarara maruz kalan orman alanlarının yakınındaki konutların değeri, ekosistem hizmetleri değeri vb. hem ormancılık hem de ormancılık dışı sektörlere yönelik etkiler bağlamında pek çok açıdan kapsamlı ve derinlemesine araştırılmıştır. Dolayısıyla söz konusu etkiler ülkemizdeki durumla kıyaslandığında hem piyasa odaklı hem de piyasa dışı etki belirleme yaklaşımları bağlamındaki tüm bileşenlerin ( $\mathrm{A}$, $B, C, D, E$,
F, G, H) yurt dışında kullanıldı̆̆ı ve elde edilen bulgulara göre ormancllık ve ilişkili sektörlerin (turizm, konut vb.) yöneticilerine yol gösterici öneri ve stratejiler sunulduğu görülmektedir.

Sonuç olarak, gerek yurt içinde gerekse yurt dışındaki çalışmalar genel olarak irdelendiğinde, ormanlarda zarar yapan böcekler, odun kökenli ürünlerin piyasa değerini doğrudan etkilemesi yanı sıra rekreasyon, görsel cazibe vb. gibi özellikle odun dışı faydaları da dolaylı olarak etkileyebilmektedir. Bir başka ifadeyle ormanlardan sağlanan pazarı olan ya da olmayan faydaların sürekliliğinin sekteye uğratılmasına neden olan böcek zararlarından kaynaklanan bu etkilerin ekonomik sonuçlar doğurması kaçınılmazdır. Böceklerle mücadelenin de bir ekonomik maliyete neden olduğu dikkate alındığında mücadele için katlanılan maliyetin gerekliliği ya da rasyonel bir tercih olup olmaması mücadele yapılması durumunda ortaya çıkması muhtemel tüm ekonomik zarar türlerinin sonuçlarıyla yakından ilişkilidir. Bu bağlamda ülkemizde bu güne kadar böcekle mücadele için yapılan harcamalar ile fiziksel olarak zarar görmüş ürün hacminden hareketle ürünlerdeki değer kaybını ve buna bağlı olarak işletmelerin gelir kaybını tahmin etmeye yönelik çalışmalar yerel ya da ulusal düzeyde böcekle mücadeleye ilişkin politika ve strateji geliştirmeye dönük yeterli katkı sağlamaktan uzaktır.

Ülkemizde bahse konu böcek zararlarının ekonomik etkilerinin belirlenmesine yönelik çalışmaların henüz başlangıç aşamasında olduğu ve geliştirilmeye muhtaç olduğu anlaşılmaktadır. Son yıllarda nüfus artışı, çevre sorunları, iklim değişimi vb. gelişmelerle birlikte orman kaynaklarının odun dışı faydalarının önemini artırması, toplam ekonomik değer / etki yaklaşımından hareketle orman ekosisteminin tüm ürün ve hizmetlerini / 
faydalarını dikkate alan etki belirleme yaklaşımlarına ilişkin araştırmaların önemini artırmıştır. O nedenle ileride yürütülecek ekonomik etki belirleme çalışmalarında, Ülkemizde yürütülen mevcut çalışmalara (Zarar önleme ve zararla mücadele maliyetleri ile piyasa fiyatı ve işletme gelirlerine etkisine ilişkin çalışmalar) ilaveten piyasa odaklı ve piyasa dışı diğer ekonomik etki belirleme yaklaşımları (maliyet etkinliği, erken kesim zararı, üretici ve tüketici refahındaki değişim, rekresayon değeri, emlak değeri, ekosistem hizmeti değeri) ve bu yaklaşımlara hizmet eden yöntemlerden (koşullu değerlendirme, hedonik fiyatlama, seyahat maliyeti vb.) de istifade edilmelidir.

\section{KAYNAKLAR}

Aksu Y, Dedeağaoğlu C, Çelik Götürk B, (2014) Picea orientalis (L.) Ormanlarında Zarar Yapan Ips amitinus (Eichhoff) 1836 (Coleoptera: Curculionidae)'un Biyolojisi ve Zarar Durumu, Türkiye II. Orman Entomolojisi ve Patolojisi Sempozyumu Bildiri Kitabı İçinde, (Toper Kaygın A., Ed.), Antalya, ss.197-203

Akyol A, Tolunay A, (2006) Türkiye'de sürdürülebilir orman kaynakları yönetimi, ilkeleri, göstergeleri ve uygulamaları, SDÜ Fen Bilimleri Enstitüsü Dergisi, 10(2), 221-234

Anonim (1963) Kalkınma Planı (I. Beş Yıl)1963-1967, http://www.sbb.gov.tr/kalkinma-planlari/, [Erişim 20 Ocak 2019]

Anonim (1968) İkinci Beş Yıllık Kalkınma Planı (1968-1972), http://www.sbb.gov.tr/kalkinma-planlari/, [Erişim 20 Ocak 2019]

Anonim (1973) Üçüncü Beş Yıllık Kalkınma Planı (1973-1977), http://www.sbb.gov.tr/kalkinma-planlari/, [Erişim 20 Ocak 2019]

Anonim (1977) Dördüncü Beş Yıllık Kalkınma Planı Özel İhtisas Komisyonu Raporu - Ormancılık Ve Orman Ürünleri Sanayi : Cilt I, DPT 1583, Öik 267, Ankara, $288 \mathrm{~s}$

Anonim (1979) Dördüncü Beş Yıllık Kalkınma Planı (1979-1983), ht http://www.sbb.gov.tr/kalkinma-planlari/, [Erişim 20 Ocak 2019]

Anonim (1985a) Beşinci Beş Yıllık Kalkınma Planı (1985-1989), http://www.sbb.gov.tr/kalkinma-planlari/, [Erişim 20 Ocak 2019]

Anonim (1985b) Beşinci Beş Yıllık Kalkınma Planı Özel ihtisas Komisyonu Raporu-Ormancılık, DPT 2006, Öik 310, Ankara, $429 \mathrm{~s}$

Anonim (1990a) Altıncı Beş Yıllık Kalkınma Planı Ormancılık Özel Ihtisas Komisyonu Raporu, DPT 2201, ÖiK 350, Ankara, 593 s

Anonim (1990b) Altıncı Beş Yıllık Kalkınma Planı (1990-1994), http://www.sbb.gov.tr/kalkinma-planlari/, [Erişim 20 Ocak 2019]

Anonim (1991) Pest risk assessment of the importation of larch from siberia and the soviet far east, https://www.fs.usda.gov/treesearch/pubs/6632, [Erişim 30 Ocak 2019]

Anonim (1995) Yedinci Beş Yıllık Kalkınma Planı Ormancılık Özel intisas Komisyonu Raporu, DPT 2400, ÖiK 461, Ankara, 575 s

Anonim (1996) Yedinci Beş Yıllık Kalkınma Planı (1996-2000), http://www.sbb.gov.tr/kalkinma-planlari/, [Erişim 20 Ocak 2019]

Anonim (2000) Uzun Vadeli Strateji ve Sekizinci Beş Yıllık Kalkınma Planı (2001-2005), http://www.sbb.gov.tr/kalkinma-planlari/, [Erişim 20 Ocak 2019]

Anonim (2001) Sekizinci Beş Yıllık Kalkınma Planı Ormancılık Özel intisas Komisyonu Raporu, DPT 2531, ÖiK 547, Ankara, 539 s
Anonim (2003) Orman Zararlıları ile Mücadele 2003 Yılı Değerlendirmesi, http://www.ogm.gov.tr/koruma/yukle.htm, [Erişim 19 Nisan 2007].

Anonim (2004a) Ulusal ormancılık programı, Çevre ve Orman Bakanlığı, Ankara, $89 \mathrm{~s}$

Anonim (2004b) Dendroctonus Micans (Great Spruce Bark Beetle) economic appraisal of control options, http://www.forestry.gov.uk/pdf/EconomicappraisalJune04.pdf/\$ FILE/EconomicappraisalJune04.pdf, [Erişim 12 Aralık 2006]

Anonim (2006) Dokuzuncu Kalkınma Planı (2007-2013), http://www.sbb.gov.tr/kalkinma-planlari/, [Erişim 20 Ocak 2019]

Anonim (2007) Dokuzuncu Kalkınma Planı Ormancılık Özel ihtisas Komisyonu Raporu, DPT 2712, Öik 665, Ankara, 102 s

Anonim (2013) Onuncu Kalkınma Planı (2007-2013), http://www.sbb.gov.tr/kalkinma-planlari/, [Erişim 20 Ocak 2019]

Anonim (2014) Onuncu Kalkınma Planı Sürdürülebilir Orman Yönetimi Özel Ihtisas Komisyonu Raporu, KB 2872, ÖiK 722, Ankara, 86 s

Anonim (2017) Orman Genel Müdürlüğü 2016 Yılı Faaliyet Raporu, https://www.ogm.gov.tr/ekutuphane/FaaliyetRaporu/Forms/Alllt ems.aspx, [Erişim 20 Ocak 2019]

Arnberger A, Ebenberger M, Schlueter IE, Cottrell S, Schneider AC, Ruschkowski E, Venette RC, Snyder SA, Gobster PH (2018) Visitor preferences for visual changes in bark beetle-impacted forest recreation settings in the United States and Germany, Environmental Management, 61(2), 209-223

Asaro C, Carter DR, Berisford CW (2006) Control of low-level Nantucket pine tip moth populations: A cost benefit analysis. Southern Journal of Applied Forestry, 30(4), 182-187

Aytar F (2006) Pozantı işletmesi ormanlarında zarar yapan böcekler ve mücadelesi, Doğu Akdeniz Ormancılık Araştırma Enstitüsü Müdürlüğü Dergisi, 12 (1), 107-164

Baş R (1972) Orman kaynaklarımızdan optimal faydalanma ile ilgili orman korunması sorunları, İstanbul Üniversitesi Orman Fakültesi Dergisi-B, 22(11), 176-184

Berkel A, Bozkurt, Y ve Göker Y (1965) Çam kerestelerinin mavi renk mantarlarına karşı korunmasına ait bir deneme, iÜ Orman Fakültesi Dergisi-A, 15 (2), 1-22

Bigsby H, Evans E, Lee D, Alavalapati J (2003) Economics of managing invasive species in tropical and sub-tropical areas of The U.S.A.: Case Study Development, Working Papers 15654, University of Florida, International Agricultural Trade and Policy Center

Born W, Rauschmayer F, Bräuer I (2005) Economic evaluation of biological invasions-a survey, Ecological Economics, 55(3), 321336

Cameron NL, Carnegie AJ, Wardlaw T, Lawson S, Venn T (2018) Economic appraisal of Sirex Wood Wasp (Sirex noctilio) control in Australian pine plantations, Australian forestry, 81(1), 37-45

Çanakçıoğlu H (1989) Orman Entomolojisi (Genel Bölüm), İstanbul Üniversitesi Orman Fakültesi Yayın No: 382, İstanbul

Çanakçıŏlu H (1993) Orman Entomolojisi (Özel Bölüm), İstanbul Üniversitesi Orman Fakültesi Yayın No: 412, İstanbul

Çatal Y, Carus S (2017) Kümeleme analizi ile orman bölge müdürlüklerinin olağanüstü hasılat etasına göre sınıflandırılması, Turkish Journal of Forestry, 18(1), 119-124

Dale VH, Joyce LA, McNulty S, Neilson RP, Ayres MP, Flannigan MD, Simberloff D (2001) Climate change and forest disturbances, BioScience, 51(9), 723-734

Defne M (1954) Ips sexdentatus Boerner Kabuk böceğinin Çoruh ormanlarındaki durumu ve tevlit ettiği zararlar, ìstanbul Üniversitesi Orman Fakültesi Dergisi, 4(2), 80-91

Dikilitaş K, Öztürk A (2010) Artvin Orman Bölge Müdürlüğü Son Beş Yılık Açık Artırmalı Satışlarının Irdelenmesi, III. Ulusal Karadeniz 
Ormancılık Kongresi Bildiriler Kitabı (Cilt I) İçinde, Artvin, ss 259269

Dikilitaş K, Öztürk A (2005) Artvin Orman Bölge Müdürlüğünde Ladin Emvali Pazarlanmasında Karşılaşılan Sorunlar ve Çözüm Önerileri, Ladin Sempozyumu Bildiriler Kitabı İçinde (Eroğlu M ve ark., Eds.), Trabzon, ss. 635-644

Downing M, O'Brien JG (2004) The exotic forest pest information system for North America- Participant's Guidelines, https://www.landcan.org/article/ExFor-The-Exotic-Forest-PestInformation-System-for-North-America-ParticipantsGuidelines/1669 [Erişim 12 Mayıs 2018]

Franklin A, De Cannière C, Grégoire JC (2004) Can sales of infested timber be used to quantify attacks by Ips typographus (Coleoptera, Scolytidae)? A pilot study from Belgium, Ann. For. Sci., 61(5), 477480

Gatto P, Zocca A, Battisti A, Barrento MJ, Branco M, Paiva MR (2009) Economic assessment of managing processionary moth in pine forests: A case-study in Portugal. Journal of environmental management, 90(2), 683-691

Güngör E, Daşdemir i (2014) Bartın Yöresi Ormanlarında Büyük Göknar Kabuk Böceği Pityokteines curvidens Germ. Zararlısının Ekonomik Etkileri, Türkiye II. Orman Entomolojisi ve Patolojisi Sem. Kitabı içinde, (Toper Kaygın A, Ed.), Antalya, ss.179-196

Haefele M, Kramer RA, Holmes T (1992) Estimating the total value of forest quality in high-elevation spruce-fir forests, The Economic Value of Wilderness: Proceedings of the Conference İçinde (Payne C, Bowker JM, Reed PC, Ed.), Asheville, NC, ss. 91-96

Haefele MA, Loomis JB (2001) Using the conjoint analysis technique for the estimation of passive use values of forest health, Journal of Forest Economics, 7(1), 9-24

Holmes TP, Murphy EA, Bell KP (2006) Exotic forest insects and residential property values, Agricultural and Resource Economics Review, 35(1), 155-166

Holmes TP (1991) Price and welfare effects of catastrophic forest damage from southern pine betle epidemics, Forest Science, 37(2), 500-516

Holmes TP, Kramer RA (1996) Contingent valuation of ecosystem health, Ecosystem Health, 2(1), 1-5

Holmes TP, Prestemon JP, Abt KL, (Ed.) (2008) The Economics of forest disturbances: wildfires, storms, and Invasive species, Springer Science \& Business Media, USA, $430 \mathrm{~s}$

Huggett Jr RJ, Murphy EA, Holmes TP (2008) Forest disturbance impacts on residential property values, The Economics of Forest Disturbances: Wildfires, Storms, And İnvasive Species'in İçinde (Holmes TP, Prestemon JP, Abt KL, Ed.), Springer Science \& Business Media, USA, ss. 209-228

Ivantsova ED, Pyzhev Al, Zander EV (2019) Economic consequences of insect pests outbreaks in boreal forests: A literature review, Journal of Siberian Federal University Humanities \& Social Sciences, 4 (12), 627-642

Jakus P, Smith VK (1991) Measuring use and nonuse values for landscape amenities: a contingent behavior analysis of gypsy moth control, Discussion paper QE92-07. Washington, DC: Resources for the Future, $48 \mathrm{~s}$

Kantay R, Köse C (2009) Orman işletme depoları ve depolama teknikleri, İstanbul Üniversitesi Orman Fakültesi Dergisi, 59(1), 7592

Komut O, İmamoğlu S, Öztürk A (2010) Orman işletmeleri satış depolarında etkili olan zararlar ve alınabilecek önlemler, III. Ulusal Karadeniz Ormancılık Kongresi Bildiriler Kitabı (Cilt I) İçinde, Artvin, ss $270-278$

Kramer RA, Holmes TP, Haefele M (2003) Contingent valuation of forest ecosystem protection, Forests in a Market Economy'nin
İçinde (Sills EO, Abt KL, Ed.), Boston: Kluwer Academic Publishers, ss 303-320.

Leuschner WA, Young RL (1978) Estimating the southern pine beetle's impact on reservoir campsites, Forest Science, 24(4), 527-537

Loomis JB, Walsh RG (1988) Net Economic Benefits of Recreation as a Function of Tree Stand Density, Proceedings: Future Forests of The Mountain West: A Stand Culture Symposium'un İçinde (Schmidt WC, Ed.), Ogden, UT: U.S. Department of Agriculture, Forest Service, Intermountain Research Station, ss. 370-375

Lysak T, Ross DW (2006) Predicting Spruce Weevil Damage in Sitka Spruce in the Norhern Oregon Coast Range, Western Journal of Applied Forestry, 21(3), 159-164.

Lyytikäinen -Saarenmaa P (2003) Growth responses and mortality of scots pine (pinus sylvestris) after a pine sawfly outbreak, Proceedings: IUFRO Kanazawa 2003 "Forest Insect Population Dynamics and Host Influences'ın İçinde (Kamata N, Liebhold AM, Quiring DT, Clancy KM, Ed.), Japan, ss. 81-85, http://kamatan.uf.au-tokyo.ac.jp/symp/iufro2003kazanawa/proceedings/19-1330saarenmaa.pdf, [Erişim 19 Nisan 2007]

McCollum DW, Lundquist JE (2019) Bark beetle infestation of western US forests: A context for assessing and evaluating impacts, Journal of Forestry, 117(2), 171-177.

Michalson EL (1975) Economic impact of mountain pine beetle on outdoor recreation, Southern Journal of Agricultural Economics, $7(2), 43-50$

Miller JD, Lindsay BE (1993) Willingness to pay for a state gypsy moth control program in New Hampshire: a contingent valuation case study, Journal of Economic Entomology, 86(3), 828-837

Moeller GH, Marler RL, McCay RE, White WB (1977) Economic analysis of the gypsy moth problem in the northeast: III Impacts on homeowners and managers of recreation areas, Res. Pap. NE-360. Upper Darby, PA: U.S. Department of Agriculture, Forest Service, Northeastern Forest Experiment Station, $9 \mathrm{~s}$

OGM (2019) Ormancilı Istatistikleri 2018, https://www.ogm.gov.tr/ekutuphane/Istatistikler/Forms/AllItems .aspx, (Erişim 25 Aralık 2019)

Olaussen JO (2005) On the economics of biological invasion: An application to recreational fishing, www.svt.ntnu.no/iso/wp/wp.htm, [Erişim 15 Nisan 2007]

O'Neill M, Evans HF (1999) Cost-effectiveness analysis of options within an Integrated Crop Management regime against great spruce bark beetle, Dendroctonus micans, Kug. (Coleoptera: Scolytidae), Agricultural and Forest Entomology, 1(2), 151- 156

Özder MZ, Keskinalemdar E (1992) Orman Amenajmanında Böcek Faktörü, Ormancılığımızda Orman Amenajmanının Dünü, Bugünü ve Geleceğine İlişkin Genel Görüşme Bildiriler Kitabı İçinde, (Eler Ü, Ed.), Orman Bakanlığı Orman genel Müdürlüğü Orman idaresi ve Planlama Dairesi Başkanlığı, Ankara

Öztürk A, Kayacan B, Dikilitaş K (2008) Kabuk böceklerinin tomruk satışları üzerine etkisi: Artvin Orman Bölge Müdürlüğünde bir ön araştırma, Doğu Akdeniz Ormancılık Araştırma Müdürlüğü Dergisi, (14), 119-130

Öztürk A, Kayacan B, Dikilitaş K (2011) A linear price model for insectdamaged industrial roundwood: A case study in Northeastern Turkey, African Journal of Business Management, 5(21), 85528557

Patriquin M, W White (2004) Assessing the economic impacts of mountain pine beetle infestations in the northern interior of British Columbia, Mountain pine beetle symposium: challenges and solutions'un İçinde (Shore TL, Brooks, JE, Stone JE, Ed.) Kelowna, British Columbia, S 223-232, http://www.for.gov.bc.ca/hfd/library/lib_MPB.htm\#w, (Erişim 24 Nisan 2007) 
Payne BR, White WB, McCay RE, McNichols RR (1973) Economic Analysis of the Gypsy Moth Problem, The Northeast. II: Applied to Residential Property, Res. Pap. NE-285. Upper Darby, PA: U.S. Department of Agriculture, Forest Service, Northeastern Forest Experiment Station, $6 \mathrm{~s}$

Price JI, McCollum DW, Berrens RP (2010) Insect infestation and residential property values: $A$ hedonic analysis of the mountain pine beetle epidemic, Forest Policy and Economics, 12(6), 415-422

Rosenberger RS, Smith EL (1997) Nonmarket economic impacts of forest insect pests: a literature review. Gen. Tech. Rep. PSW-GTR164-www. Albany, CA: Pacific Southwest Research Station, Forest Service, U.S. Department of Agriculture, $38 \mathrm{~s}$

Rosenberger Randall S, Bell Lauren A, Champ Patricia A, Smith Eric L (2012) Nonmarket economic values of forest insect pests: An updated literature review, Gen. Tech. Rep. RMRS-GTR-275WWW. $46 \mathrm{~s}$

Rosenberger SR, Bell LA, Champ PA, White ES (2013) Estimating the economic value of recreation losses in Rocky Mountain National Park due to a mountain pine beetle outbreak, Western Economics Forum, 12(1), 31-39

Saraçoğlu N (2014) Böcek Zararlısı Odunların Enerji Üretiminde Kullanılması, Türkiye II. Orman Entomolojisi ve Patolojisi Sempozyumu Bildiri Kitabı İçinde, (Toper Kaygın A, Ed.), Antalya, ss 255-260

Sarıkaya O, Avcı M (2006) Kabuk böceklerine karşı ormanlarımızda alınabilecek koruyucu önlemler, Orman Mühendisliği Dergisi, 43 $(1,2,3), 26-31$

Sertkaya İ (2010) Avrupa Birliği ve Ülkemiz Ormanlarında Toplu Ağaç Ölümlerine Sebep Olan Kabuk Böceklerinin Çevresel Etkilerinin incelenmesi, AÜ Avrupa Toplulukları Araştırma ve Uygulama Merkezi 46. Dönem AB Temel Eğitim Kursu, Ankara

Thompson R, Hanna R, Noel J, Piirto D (1999) Valuation of tree aesthetics on small urban-interface properties, Journal of Arborculture, 25(5), 225-234

Tkacz BM (2002) Pest risks associated with importing wood to the United States1 Canadian Journal of Plant Pathology, 24(2), 111116

Tkacz BM, Burdsall, HH, DeNitto, GA, Eglitis A, Hanson, JB, Kliejunas, JT, Wallner, WE, O'Brien, JG, Smith EL (1998) Pest risk assessment of the importation into the United States of unprocessed Pinus and Abies logs from Mexico, Gen. Tech. Rep. FPL-GTR-104. Madison, $116 \mathrm{~s}$
Toper Kaygın A (2003) Batı Karadeniz Bölümünde Abies bornmülleriana Mattf. Ağaçlarında tespit edilen bazı zararlı böcekler ve bunların önemi, Gazi Üniversitesi Orman Fakültesi Dergisi-Kastamonu, 3(2), 143-154

Toprak Ö (2014) Çam keseböceği (Thaumetopoea pityocampa Schiff.)'nin entegre mücadelesinde Calosoma sycophanta (L.)'nın üretimi, Türkiye II. Orman Entomolojisi ve Patolojisi Semp. Bildiri Kitabı İçinde, (Toper Kaygın A, Ed.), Antalya, ss. 349-360

Wallner WE (1997) Global Gypsy - The Moth That Gets Around, Exotic Pests of Eastern Forests Conference, Proceedings'in İçinde (Britton KO, Ed.), http://www.invasive.org/symposium/wallner.html [Erişim 8 Mart 2007]

Walsh RG, Bjonback RD, Aiken RA, Rosenthal DH (1990) Estimating the public benefits of protecting forest quality, Journal of Environmental Management, 30(2), 175-189.

Walsh RG, Keleta G, Olienyk JP (1981a) Value of trees to residential property owners with mountain pine beetle and spruce budworm damage in the Colorado Front Range, Colorado State University for U.S. Department of Agriculture, Forest Service, $116 \mathrm{~s}$

Walsh RG, Olienyk JP (1981) Recreation demand effects of mountain pine beetle damage to the quality of forest recreation resources in the Colorado Front Range. Fort Collins, (Contract No. 53-82X9-9180). $87 \mathrm{~s}$

Walsh RG, Ward FA, Olienyk JP (1989) Recreational demand for trees in national forests, Journal of Environmental Management, 28(3), 255-268

Walsh RG, Keleta G, Olienyk JP, Waples EO (1981b) Appraised market value of trees on residential property with mountain pine beetle and spruce budworm damage in the Colorado Front Range, Fort Collins, CO: Colorado State University for U.S. Department of Agriculture, Forest Service (Cooperative Agreement 16-950-CA). $150 \mathrm{~s}$

Wickman BE, Renton DA (1975) Evaluating damage caused to a campground by Douglas-fir tussock moth, Res. Note PNW-257. Portland, $5 \mathrm{~s}$

Yazıcı H, Yalçın A (2005) Hatila Vadisi Milli Parkında Ladin Kabuklu Böceklerine Karşı Yürütülen Mücadele Çalışmalarında Yönetim ve iş Organizasyonu, Ladin Sempozyumu Bildiriler Kitabı İçinde (Eroğlu M ve ark., Eds.), Trabzon, ss 241-246

Yılmaz E, Saraçoğlu Ö, Aytar F, Ulusoy R (2009) Ormancılıkta entegre zararlı yönetimi (ezy) uygulamalarının koşul, olanak ve darboğazları: OZM şube müdürlüğü çalışanlarının görüşleri, Doğu Akdeniz Orm. Araştırma Enstitüsü, Yayın No: 53, 99 s 